WSRC-TR-99-00390

Rev. 0

\title{
Soil Vapor Extraction Testing of Selected Wells In the Northern Sector of A-Area
}

Publication Date: February, 2000

Westinghouse Savannah River Company

Savannah River Site

Aiken, SC 29808

Prepared for the U. S. Department of Energy under contract no. DE-AC09-96SR18500 
This document was prepared in conjunction with work accomplished under Contract No.

DE-AC09-96SR18500 with the U.S. Department of Energy.

\section{DISCLAIMER}

This report was prepared as an account of work sponsored by an agency of the United States Government. Neither the United States Government nor any agency thereof, nor any of their employees, makes any warranty, express or implied, or assumes any legal liability or responsibility for the accuracy, completeness, or usefulness of any information, apparatus, product or process disclosed, or represents that its use would not infringe privately owned rights. Reference herein to any specific commercial product, process or service by trade name, trademark, manufacturer, or otherwise does not necessarily constitute or imply its endorsement, recommendation, or favoring by the United States Government or any agency

thereof. The views and opinions of authors expressed herein do not necessarily state or reflect those of the United States Government or any agency thereof.

This report has been reproduced directly from the best available copy.

Available for sale to the public, in paper, from: U.S. Department of Commerce, National Technical Information Service, 5285 Port Royal Road, Springfield, VA 22161, phone: (800)

553-6847, fax: (703) 605-6900, email: orders@ntis.fedworld.gov online ordering: http://www.ntis.gov/ordering.htm

Available electronically at http://www.doe.gov/bridge

Available for a processing fee to U.S. Department of Energy and its contractors, in paper, from: U.S. Department of Energy, Office of Scientific and Technical Information, P.O. Box 62, Oak Ridge, TN 37831-0062, phone: (865 ) 576-8401, fax: (865) 576-5728, email: reports@ adonis.osti.gov 
WSRC-TR-99-00390, Rev. O

Soil Vapor Extraction Testing of Selected Wells

In the Northern Sector of A-Area

Prepared by:

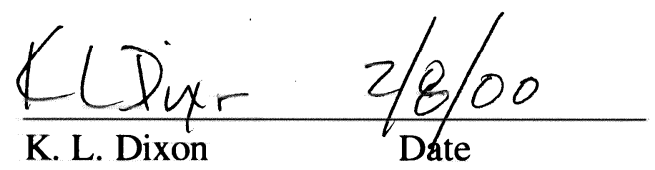

Reviewed by:

$\frac{\text { Brian B. foamy } \phi 8 F E B}{\text { B. B. Loony }} 2 \phi \phi \phi$

Reviewed by:

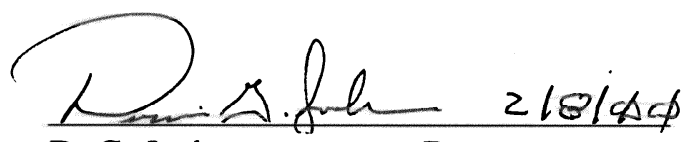

D. G. Jackson

Date

Approved by:

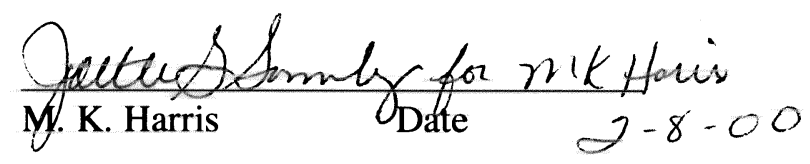




\section{Table Of Contents}

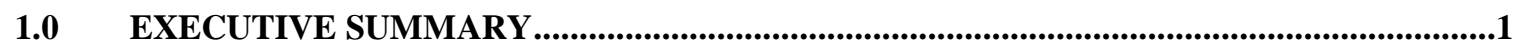

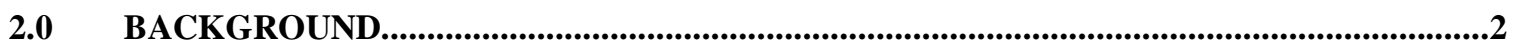

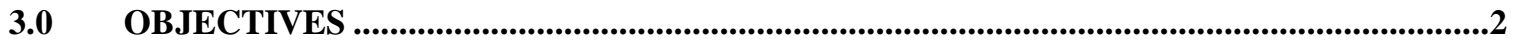

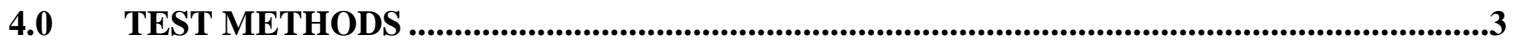

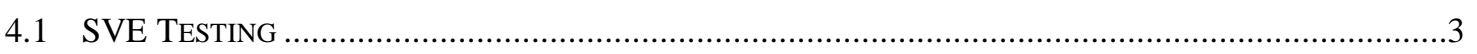

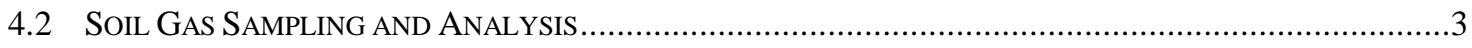

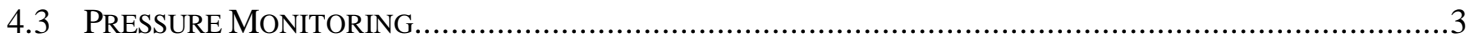

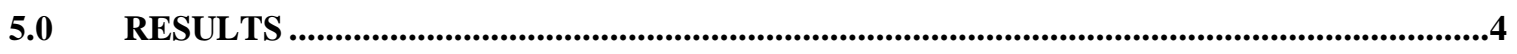

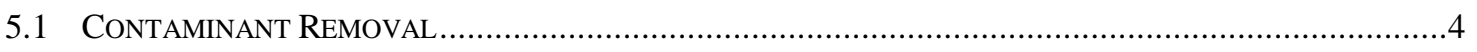

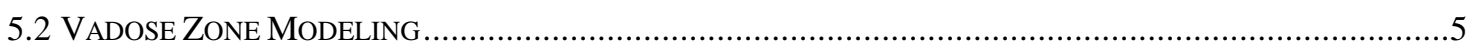

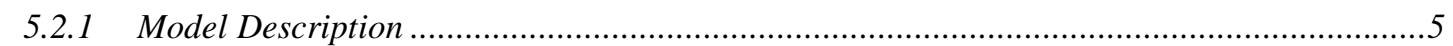

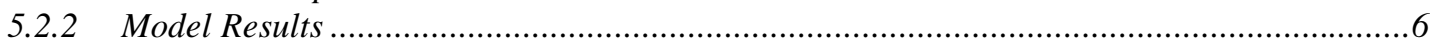

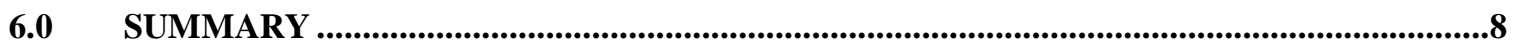

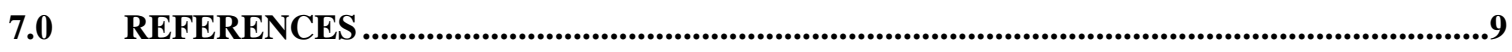




\section{List of Figures}

FIGURE 1. LOCATION OF THE NORTHERN SECTOR SVE TEST WELLS .............................................10

Figure 2. Trailer Mounted Portable SVE UnIT USED IN NORTHERN SECTOR TESTING ....................11

Figure 3. WELl CONSTRUCTION DETAILS FOR THE NORTHERN SECTOR TEST WELlS.............................12

FIGURE 4. TCE CONCENTRATIONS AS A FUNCTION OF TIME FOR TEST 3 ON MSB 67D ........................13

Figure 5. CuMUlative TCE MASS REMOVED AS A FunCTION OF TIME FOR TEST 3 ON MSB 67D............14

FIGURE 6. TCE CONCENTRATIONS AS A FUNCTION OF TIME FOR TEST 4 ON MSB 68D ..........................15

Figure 7. Cumulative TCE MASS REMOVED AS A FunCTION OF TIME FOR TEST 4 ON MSB 68D............16

FIGURE 8. VACUUM DRAWDOWN AS FUNCTION OF TIME FOR MSB 68D. ....................................17

\section{List of Tables}

TABLE 1. WELLS UTILIZED IN THE NORTHERN SECTOR SVE TEST ...............................................

TABLE 2. ReSUlts OF SVE TeSting ON THE NORTHERN SECTOR WELLS ......................................18 


\section{LIST OF ACRONYMS}

$\begin{array}{ll}\text { B\&K } & \text { Brüel \& Kjær } \\ \text { CVOC } & \text { Chlorinated volatile organic compound } \\ \text { ECD } & \text { Electron capture detector } \\ \text { FID } & \text { Flame ionization detector } \\ \text { GC } & \text { Gas chromatograph } \\ \text { HP } & \text { Hewlett Packard } \\ \text { LFG\&E } & \text { Landfill Gas and Environmental Products, Inc. } \\ \text { PCE } & \text { Perchloroethylene } \\ \text { ppmv } & \text { part per million by volume } \\ \text { RTV } & \text { room temperature vulcanization } \\ \text { scfm } & \text { standard cubic feet per minute } \\ \text { STP } & \text { standard temperature and pressure } \\ \text { SRS } & \text { Savannah River Site } \\ \text { SRL } & \text { Savannah River Laboratory } \\ \text { SRTC } & \text { Savannah River Technology Center } \\ \text { SVE } & \text { Soil vapor extraction } \\ \text { SVEU } & \text { Soil vapor extraction unit } \\ \text { TCE } & \text { Trichloroethylene } \\ \text { WSRC } & \text { Westinghouse Savannah River Company }\end{array}$




\subsection{Executive Summary}

The A/M-Area is located in the northern section of the Savannah River Site (SRS) and consists of facilities that fabricated reactor fuel and target assemblies for the SRS reactors (M-Area), laboratory facilities (SRTC, formally SRL), and administrative and support facilities (A-Area). Operations at these and other facilities within the $\mathrm{A} / \mathrm{M}$ Area resulted in the release of chlorinated volatile organic compounds (CVOC) to the subsurface. Significant CVOC contamination has been detected in the groundwater in the Northern Sector of the SRTC complex. This contamination has resulted from past uses and disposal of organic solvents in several SRTC facilities (Colven et al.,1988). Waste solvents from degreasers and other SRTC operations facilities were discharged to the A-001 outfall via unlined earthen ditches and an underground process sewer.

CVOC contamination detected in water table wells in the Northern Sector of SRTC indicates that solvents discharged to the unlined ditches have seeped through the vadose zone and into the shallow groundwater. The purpose of this testing was to determine if a vadose zone source for the contamination remains and to begin collecting data to assist with determining the location of any significant source.

Vadose zone pumping tests were performed on water table monitoring wells MSB 47D, MSB 67D, and MSB 68D. These wells are located within the aqueous phase plume based on solvent concentrations measured in these wells as part of the SRS Groundwater Monitoring Program. Wells MSB 67D and MSB 68D produced soil vapor contaminated with CVOCs. MSB 47D, which exhibited the lowest aqueous phase solvent concentrations of the three wells, did not produce contaminated soil vapor. MSB 67D was pumped for a period of 10.76 days at a flow rate of $12.6 \mathrm{scfm}$ and produced a total of 0.17 pounds of trichloroethylene. Two pumping tests were performed on MSB 68D. For the first test, MSB 68D was pumped for a period of 4.68 days at a flow rate of $32.3 \mathrm{scfm}$ and produced 1.31 pounds of trichloroethylene. For the second test, MSB 68D was pumped for a period of 5.84 days at a flow rate of $38.6 \mathrm{scfm}$ and produced 2.28 pounds of trichloroethylene.

The results of this testing indicate that there is CVOC contamination in the vadose zone of the Northern Sector; however, the results are inconclusive as to the location of the source for the contamination. Based on the CVOC concentrations observed in the groundwater for the three wells tested compared to the CVOC concentrations observed in the soil vapor from each well, none of the three wells are located in the most contaminated portion of the vadose zone plume. MSB 68D appears to be closest to a contaminated area. Future investigations should be focused upon the area surrounding MSB 68D to determine the source and extent of the vadose zone contamination.

A Hantush-Jacob leaky aquifer model was used to describe the vadose zone in the Northern Sector in an effort to estimate the permeability of the unsaturated sediments. The transmissivity of the unsaturated sediments was estimated to be $0.96 \mathrm{ft}^{2} / \mathrm{min}$. The radial permeability of the sediments $\left(\mathrm{k}_{\mathrm{r}}\right)$ was estimated to be on the order of 100 darcies, which is within the range previously measured for the central portion of A/M Area (Looney et al., 1991). Leakage values produced by the model simulations were found to be extremely small. This suggests that gas flow in this vadose zone system is similar to water flow in a confined aquifer with a competent confining layer preventing leakage from the overlying sediments. 


\subsection{Background}

The A/M-Area is located in the northern section of the Savannah River Site (SRS) and consists of facilities that fabricated reactor fuel and target assemblies for the SRS reactors (M-Area), laboratory facilities (SRTC, formally SRL), and administrative and support facilities (A-Area). Operations at these and other facilities within the A/M Area resulted in the release of chlorinated volatile organic compounds (CVOC), primarily trichloroethylene (TCE), perchloroethylene (PCE) and 1,1,1-trichloroethane (1,1,1-TCA) to the subsurface (Marine and Bledsoe, 1984). These releases have resulted in the contamination of the soil and groundwater within the area.

Significant CVOC contamination has been detected in the groundwater in the Northern Sector of the SRTC complex. This contamination has resulted from past uses and disposal of organic solvents in several SRTC facilities (Colven et al.,1988). Waste solvents from degreasers and other SRTC operations facilities were discharged to the A-001 outfall via unlined earthen ditches and an underground process sewer. Seepage of solvents from the unlined ditches has resulted in the contamination of both the vadose zone and the groundwater in the Northern Sector of SRTC.

CVOC contamination has been detected in well clusters MSB 47, MSB 67, and MSB 68. Figure 1 shows the layout of the well clusters in relation to nearby SRTC facilities. Table 1 gives the most recent trichloroethylene concentrations reported for the water table wells MSB 47D, MSB 67D, and MSB 68D. These results clearly show that volatile organic contaminants have reached the groundwater in this area. Unlike well clusters MSB 67 and 68, the maximum TCE concentrations observed in the MSB 47 cluster occur in the deeper wells. This suggests that contaminant migration has been more vertical than lateral (Colven et al., 1988). The A1/A2 air stripper system was placed into service to address the CVOC contamination in the groundwater in the Northern Sector of SRTC. The purpose of the air stripper was to treat the contaminated groundwater, and to provide hydraulic control of the contaminant plume to prevent it from migrating to the deeper aquifer systems.

The purpose of this testing was to determine if a vadose zone source for the contamination remains and to begin collecting data to assist with determining the location of any significant source. To date, there have been no characterization efforts undertaken to identify any vadose zone source for CVOC contamination in the Northern Sector of SRTC. In an effort to begin to identify and address any contamination source, soil vapor extraction (SVE) testing was undertaken on wells MSB 47D, MSB 67D, MSB 68D. These wells were chosen because of their proximity to the suspected source, the presence of dry screen, and because of the significant TCE concentrations measured in the groundwater from these wells. This testing represents the first step towards determining the source location for the vadose zone contamination. The results of this study are intended to aid in determining the path forward for remediation efforts for the Northern Sector.

\subsection{Objectives}

The objectives of the Northern Sector A-Area SVE testing were to establish the presence of CVOCs in the vadose zone in the vicinity of the test wells, and to collect data to assist in locating the source of the contamination. 


\subsection{Test Methods}

\subsection{SVE Testing}

The Northern Sector SVE testing was conducted using the wells identified in Table 1. Figure 1 gives the location of the test wells in relation to the SRTC facilities. A portable, trailer mounted SVE unit was used for testing purposes. The unit consisted of a Tuthill ${ }^{\mathrm{TM}}$ Model 5507 heavy duty, high pressure, rotary type blower driven by a $25 \mathrm{HP} 3 \phi 480$ VAC motor. Power was supplied to the system with a portable diesel generator. The unit featured a variable speed controller with pressure and temperature protection. The unit was equipped with inlet and outlet silencers for noise control, and a cyclone separator on the inlet side to protect the blower from particulate matter in the air stream. Figure 2 gives a picture of the soil vapor extraction unit (SVEU).

The SVEU was connected to each well using 2 inch diameter heavy duty Newflex® spiral reinforced PVC flexible tubing manufactured by NewAge Industries, Inc. The Newflex ${ }^{\circledR}$ tubing was connected to each well using a well head assembly constructed of Schedule 40 PVC pipe. All connections were made using standard hose clamps. Teflon tape and RTV (room temperature vulcanization) silicone sealant were used as necessary to seal the connections. Air flow rate for each extraction well was measured using a LFG\&E ORIPAC one inch diameter orifice plate flow meter. A differential pressure gauge (Magnehelic) was used to monitor the pressure drop across the plate. The differential pressure measurements were converted to flow rates using textbook equations for obstruction type flow devices (White, 1979).

\subsection{Soil Gas Sampling and Analysis}

Three single well extraction tests were conducted on wells MSB 47D, MSB 67D, and MSB 68D. During each test, a portable Bruel \& Kjaer (B\&K) Model 1302 infrared photoacoustic multi-gas monitor was used to monitor CVOC concentrations from each extraction well. The B\&K uses a photoacoustic infra-red detection method to analyze for CVOCs in the gas stream. The B\&K was configured to analyze for trichloroethylene, perchloroethylene, carbon tetrachloride, and carbon dioxide. Carbon dioxide was used to indicate the origin of the gas stream and to verify the seal between the blower and the extraction well. Soil gas and atmospheric air exhibit different concentrations of carbon dioxide gas. The concentration of carbon dioxide in atmospheric air is on the order of $500 \mathrm{ppmv}$, whereas soil gas carbon dioxide concentrations in the vadose zone (SRTC area) have been observed to be on the order of 13,000 ppmv.

Confirmation grab samples were routinely collected from the gas stream using a small vacuum pump and Tedlar $^{\mathrm{TM}}$ bags. These samples were analyzed within 24 hours of collection using a Hewlett Packard 5890 gas chromatograph equipped with a flame ionization detector (FID), electron capture detector (ECD), and a mass spectrophotometer. The samples were analyzed for trichloroethylene, carbon tetrachloride, perchloroethylene. The results of these samples were used to verify the operation of the B\&K multigas monitor.

\subsection{Pressure Monitoring}

For each test, the two wells not being pumped were used to monitor the air pressure in the vadose zone. These wells were fitted with press on PVC caps modified with tubing connections. One eighth inch polyethylene tubing was used to transmit air pressure from each well to a data logger. Air pressure in the vadose zone was monitored using a data logger equipped with a differential pressure transducer, a barometer, and a computer operated manifold. 


\subsection{Results}

Vadose zone pumping tests were performed on wells MSB 47D, MSB 67D, and MSB 68D located in the Northern Sector of SRTC. Testing was conducted with a portable trailer mounted SVEU. The unit was operated on each well at the maximum possible vacuum without causing the water level in the well to surge above the dry portion of the screen. The vacuum setting for each well was determined based on field observations and resulted in different flow rates for each well. Figure 3 shows the screened length for each well and the water level elevation in each well. This figure clearly shows that each well had dry screen making each suitable for SVE testing. Each test was operated for a period of sufficient duration to observe soil gas concentrations from each well and determine if significant changes in concentrations were occurring.

\subsection{Contaminant Removal}

The SVEU was operated on MSB 47D for a period of 6.8 days (163.2 hrs) at an average flow rate of 18.5 scfm (Table 2). CVOCs were not detected in the soil vapor from MSB 47D. This is consistent with soil gas sampling results reported by Colven et al. (1988), and corroborates the determination made by Colven et al. (1988) that migration of the contaminants away from the source has been primarily vertical rather than lateral. This is substantiated by TCE concentrations measured in the deeper wells of the cluster which range on the order of 2000 to $3000 \mu \mathrm{g} / \mathrm{L}$ (MSB 47C) compared to 1 to $2 \mu \mathrm{g} / \mathrm{L}$ for MSB 47D. Furthermore, the MSB 47 well cluster is located within a few hundred feet of a suspected source. Any significant lateral migration of the contaminant plume through the vadose zone in the direction of the MSB 47 well cluster would have likely resulted in CVOCs in the offgas from the SVE testing. Drawdown data collected while testing MSB 47D are presented in Appendix A, Table A-1.

The SVEU was operated on MSB 67D for a period of 10.8 days (258.3 hrs) at an average flow rate of 12.6 scfm (Table 2). TCE was detected in the soil vapor from MSB 67D, but the concentrations were relatively low compared to the dissolved phase concentrations observed in the groundwater (Table 1). No other CVOC was measured above the detection limit. Figure 4 shows the TCE concentration as a function of time for the test. TCE concentrations in the soil vapor ranged from 1.1 to $4.5 \mathrm{ppmv}$ with concentrations increasing over the duration of the test. The low concentrations of TCE in the soil vapor indicates that MSB 67D is located away from the main area of vadose zone contamination. The increase in TCE concentration in the soil vapor suggests that relatively cleaner air in the vicinity of the well was replaced by more contaminated air as the vadose zone contaminant plume was influenced by pumping the well. Figure 5 shows the cumulative mass of TCE removed as function of time. A total of 0.17 pounds of TCE was removed from the vadose zone over the course of the test. Drawdown data collected while testing MSB 67D are presented in Appendix A, Table A-2.

Two vadose zone pumping tests were performed on MSB 68D. For the first test, MSB 68D was pumped for a period of 4.68 days at a flow rate of $32.3 \mathrm{scfm}$. During this test, a confirmation grab sample analyzed by gas chromatograph revealed an error with the B\&K. Consequently, continuous VOC measurements were not obtained as part of the first test; however, based upon the grab sample, the TCE concentration in the soil vapor was 18.0 ppmv. Based on this concentration, a total of 1.31 pounds of TCE was removed from the vadose zone during the first test.

SVE testing was conducted a second time on MSB 68D to examine changes in VOC concentrations in the soil gas over time. During the second test, the SVEU was operated on MSB 68D for a period of 5.8 days (140.1 hrs) at an average flow rate of $38.6 \mathrm{scfm}$. TCE was detected in the soil vapor from MSB 68D; however, as with MSB 67D, the concentrations were relatively low compared to the dissolved phase concentrations observed in the groundwater (Table 1). No other CVOC was measured above the detection limit. Figure 6 shows the TCE concentrations as a function of time for the test. TCE concentrations in the soil vapor ranged from 19.8 to $20.7 \mathrm{ppmv}$ with concentrations decreasing initially and then remaining 
relatively stable over the remainder of the test. These results indicate that MSB 68D is potentially located within a vadose zone contaminant plume, but it is still some distance from the source based on the low concentrations of TCE in the soil vapor. Figure 7 shows the cumulative mass of TCE removed as a function of time for the second test. For the second test at MSB 68D, 2.28 pounds of TCE was removed from the vadose zone. Drawdown data collected while testing MSB 68D are presented in Appendix A, Tables A-3 and A-4.

\subsection{Vadose Zone Modeling}

\subsubsection{Model Description}

The pressure response of the vadose zone due to SVE pumping was modeled in order to estimate the permeability of the unsaturated sediments. Drawdown data from the first pumping test performed on MSB 68D was used in the analysis. This test was chosen because the data set included both the drawdown and recovery periods, and because this test produced the greatest amount of drawdown in the observation well.

Barometric pressure fluctuates almost continually even during periods of high pressure. These pressure fluctuations are transmitted through the unsaturated subsurface in the form of pressure waves which are typically damped and delayed to degrees dependent on the effective permeability of the unsaturated media (Buckingham, 1904; Weeks, 1978). As a result of the attenuation and delay of the transmitted pressure wave, at a given time, the atmospheric pressure at the surface and the soil gas pressure in the subsurface will be different (Rossabi, 1999). The dampened pressure wave associated with barometric pressure fluctuations is manifested in any data collected from a pumping test. Thus, it is necessary prior to interpreting data from vadose zone pumping tests, to separate out the barometric component. This is particularly important when the measured drawdown is expected to be on the same scale as the barometric fluctuations. A common method for separating out barometric effects is to make use of a reference well (Massmann, 1989). Ideally, the reference well is located out of the area of influence of the pumping test, but screened within the zone of interest. Subsurface gas pressure is monitored in the reference well in addition to the observation wells used in the pumping test. Because the reference well is distant from the pumping well, there will be minimal drawdown observed at that location. Therefore, fluctuations in gas pressure in the reference well can be directly attributed to fluctuations in barometric pressure and the propagation of these fluctuations through the geologic section. The pressure wave from the reference well is then used to correct the pressure waves measured in the observation wells for barometric pressure fluctuations. This method was chosen for the analysis of the pumping data from MSB 68D.

For analysis purposes, MSB 47D was designated as the observation well. MSB 47D is located about 250 $\mathrm{ft}$ from the pumping well (MSB 68D), which is near the outer limits of the radius of influence of the test. This is corroborated by the small drawdown values measured at MSB 47D $\left(\sim 0.2\right.$ in $\left.\mathrm{H}_{2} \mathrm{O}\right)$. MSB $67 \mathrm{D}$ is located about $335 \mathrm{ft}$ from the pumping well. Drawdown in MSB 67D was determined to be negligible and it was subsequently designated as the reference well.

Differential pressure was measured in both MSB 47D and 67D. Barometric pressure data was obtained from the SRTC weather center. The absolute gas pressure in each well was determined by adding the differential pressure to the barometric pressure. The absolute pressure measured in MSB 47D was then subtracted from the absolute pressure measured in MSB 67D. This removed any barometric fluctuations from the observation data. All pressure measurements were logged in units of millibars, which were converted into units of feet of water. The units of feet of water were then converted to feet of air by multiplying by the ratio of the density of water to the density of air.

The data from the test was analyzed using the program AQTESOLV, which is a program designed for pump test analysis (Geraghty and Miller Inc., 1996). A type curve matching procedure was employed using a model for leaky aquifers with partially penetrating wells. The model used was developed by 
Hantush and Jacob (1955) and Hantush (1961a and b) to analyze data from pumping tests in leaky aquifers. It has been shown that under certain conditions, standard techniques used to model groundwater pumping tests may also be used in the interpretation of data from vadose zone pumping tests (Massmann, 1989; Massmann and Madden, 1994). In the case of a vadose zone pumping test, the fluid is air rather than water. Massmann (1989) gives the assumptions and limitations associated with modeling gas transport with conventional groundwater transport equations. One of the more significant assumptions is that gas transport can be modeled using the equation for incompressible fluid flow. Massmann (1989) found that for pressure variations on the order of one half atmosphere or less this assumption is valid. For the Northern Sector SVE testing, pressure variations were less than one tenth of an atmosphere.

Parameters used in the Hantush-Jacob model for leaky aquifers includes the saturated thickness of the aquifer, the thickness of the overlying confining layer, and the zone of penetration of the pumping and observation well (or wells). For the case of a vadose zone pumping test, the fluid is air and the "saturated thickness" is equal to the thickness of the unsaturated zone minus the confining layer. For the Northern Sector, the confining layer was taken to be 60 feet in thickness based upon lithologic logs prepared during the installation of the MSB 68 well series. The water table was taken as the underlying no flow boundary condition in the Hantush-Jacob leaky aquifer model. A "saturated thickness" of 72.5 feet was used to describe the sediments between the water table and the confining layer.

\subsubsection{Model Results}

AQTESOLV simulations were performed for each test and the resulting type curves are presented in Appendix B. Looney et al. (1991) recommended implementing calculated limits for the storage coefficient in the Hantush-Jacob leaky aquifer model. The use of calculated limits prevents AQTESOLV from predicting storage coefficients greater than physically possible based upon the expected moisture content of the unsaturated zone.

The specific storage, $S_{\mathrm{s}}$, may be calculated using the following equation:

$$
S_{s}=\frac{g \phi_{a} M W}{R T}(1)
$$

where:

$\mathrm{g}=$ gravitational constant $=980 \mathrm{~cm} / \mathrm{sec}^{2}$

$\phi_{\mathrm{a}}=$ available porosity

$\mathrm{MW}=$ molecular weight of gas (air) $=28 \mathrm{~g} / \mathrm{mol}$

$\mathrm{RT}=$ gas constant $*$ absolute temperature $=2.5 \times 10^{10} \mathrm{~cm}^{2} \mathrm{~g} / \mathrm{mol} \mathrm{sec}{ }^{2}$

The available porosity, $\phi_{\mathrm{a}}$ may be calculated using the following equation:

$\phi_{a}=\phi_{t}\left(1-\theta_{s}\right)$

where:

$\phi_{\mathrm{t}}=$ total porosity, 0.4 (Eddy et al., 1991)

$\theta_{\mathrm{s}}=$ saturation 
The storage coefficient, S, may then be determined with the following equation:

$S=S_{s} b$

where:

$\mathrm{b}=$ thickness of the unsaturated zone

A storage coefficient of 0.00065 was calculated based on a saturation value of 0.3 for the unsaturated zone. For modeling purposes, the storage coefficient was fixed to 0.00065 and transmissivity and leakage were iterated to produce the best fit of the data.

Figure 8 gives the results of the simulation. The transmissivity of the unsaturated sediments was estimated to be $0.96 \mathrm{ft}^{2} / \mathrm{min}$. The radial permeability of the sediments $\left(\mathrm{k}_{\mathrm{r}}\right)$ was estimated to be on the order of 100 darcies, which is within the range previously measured for the central portion of A/M Area (Looney et al., 1991). The vertical permeability $\left(\mathrm{k}_{\mathrm{z}}\right)$ of the sediments was estimated to be about 3 darcies. Leakage values produced by the model simulations were found to be extremely small $\left(1 \mathrm{X} 10^{-20}\right)$. This suggests that gas flow in this vadose zone system is similar to water flow in a confined aquifer with a competent confining layer preventing leakage from the overlying sediments. This model is consistent with the lithologic logs from MSB 68 well series which show a clay layer at about $60 \mathrm{ft}$ bgs. In this case, the Theis (1935) confined aquifer model with no leakage would be expected to yield the same results as the Hantush-Jacob leaky model. 


\subsection{Summary}

Vadose zone pumping tests were performed on wells MSB 47D, MSB 67D, and MSB 68D. Wells MSB 67D and MSB 68D produced soil vapor contaminated with CVOCs. MSB 47D did not produce contaminated soil vapor. MSB 67D was pumped for a period of 10.76 days at a flow rate of $12.6 \mathrm{scfm}$ and produced a total of 0.17 pounds of trichloroethylene. Two pumping tests were performed on MSB 68D. For the first test, MSB 68D was pumped for a period of 4.68 days at a flow rate of $32.3 \mathrm{scfm}$ and produced 1.31 pounds of trichloroethylene. For the second test, MSB 68D was pumped for a period of 5.84 days at a flow rate of $38.6 \mathrm{scfm}$ and produced 2.28 pounds of trichloroethylene.

Based on the CVOC concentrations observed in the groundwater for the three wells tested compared to the CVOC concentrations observed in the soil vapor from each well, none of the three wells are located in the most contaminated portion of the vadose zone plume. MSB 68D appears to be closest to the contaminated area. Future investigations should be focused upon the area surrounding MSB 68D to determine the source and extent of the vadose zone contamination.

A Hantush-Jacob leaky aquifer model was used to describe the vadose zone in the Northern Sector. The transmissivity of the unsaturated sediments was estimated to be $0.96 \mathrm{ft}^{2} / \mathrm{min}$. The radial permeability of the sediments $\left(\mathrm{k}_{\mathrm{r}}\right)$ was estimated to be on the order of 100 darcies, which is within the range previously measured for the central portion of A/M Area (Looney et al., 1991). Leakage values produced by the model simulations were found to be extremely small. This suggests that gas flow in this vadose zone system is similar to water flow in a confined aquifer with a competent confining layer preventing leakage from the overlying sediments. 


\subsection{References}

Buckingham, E. 1904. Contributions to our knowledge of the aeration of soils. U. S. Department of Agriculture Bureau of Soils. Bulletin 25, No. 7.

Colven, W. P., J. G. Horvath, B. B. Looney, L. F. Boone, C. L. Bergren, B. F. Fowler, and P. H. Stevens. 1988. SRL groundwater investigation and remediation program. DPSP-88-1010. E. I. du Pont de Nemours \& Co. Savannah River Plant, Aiken, SC.

Marine, I. W. and H. W. Bledsoe. 1984. Supplemental technical data summary, M-Area groundwater investigation. DPST-84-112. E. I. du Pont de Nemours \& Co. Savannah River Plant, Aiken, SC.

Hantush, M. S. and C. E. Jacob, 1955. Non-steady radial flow in an infinite leaky aquifer. American Geophysical Union Transactions. Vol. 36, pp. 95-100.

Hantush, M. S., 1961a. Drawdown around a partially penetrating well. Journal of the Hydraulics Division, Proceedings of the American Society Of Civil Engineers. Vol. 87, No. HY4, pp. 83-98.

Hantush, M. S., 1961b. Aquifer tests on partially penetrating wells. Journal of the Hydraulics Division, Proceedings of the American Society Of Civil Engineers. Vol. 87, No. HY5, pp. 171-194.

Looney, B. B., J. B. Pickett, and J. J. Malot. 1991. Pilot test of a vacuum extraction system for environmental remediation of chlorinated solvents at the Savannah River Site. WSRC-RD-91-19. Westinghouse Savannah River Company, Savannah River Site, Aiken SC.

Massmann, J .W. 1989. Applying groundwater flow models in vapor extraction system design. Journal of Environmental Engineering, American Society of Civil Engineers. Vol. 115, No. 1, pp. 129-149.

Massmann, J. W. and M Madden. 1994. Estimating air conductivity and porosity from vadose zone pumping tests. Journal of Environmental Engineering, American Society of Civil Engineers. Vol. 120, No. 2, pp. 313-327.

Rossabi, J. 1999. The influence of atmospheric pressure variations on subsurface soil gas and the implications for environmental characterization and remediation. Doctoral Dissertation, Clemson University. University of Michigan Press.

Theis, C. V. 1935. The relation between the lowering of the piezometric surface and the rate and duration of discharge of a well using groundwater storage. American Geophysical Union Transactions. Vol. 16, pp. 519-524.

Weeks, E. P. 1978. Field determination of vertical permeability to air in the unsaturated zone. U. S. Geological Survey Professional Paper 1051.

White, F. M. 1979. Fluid Mechanics. McGraw-Hill, Inc. New York, NY. 


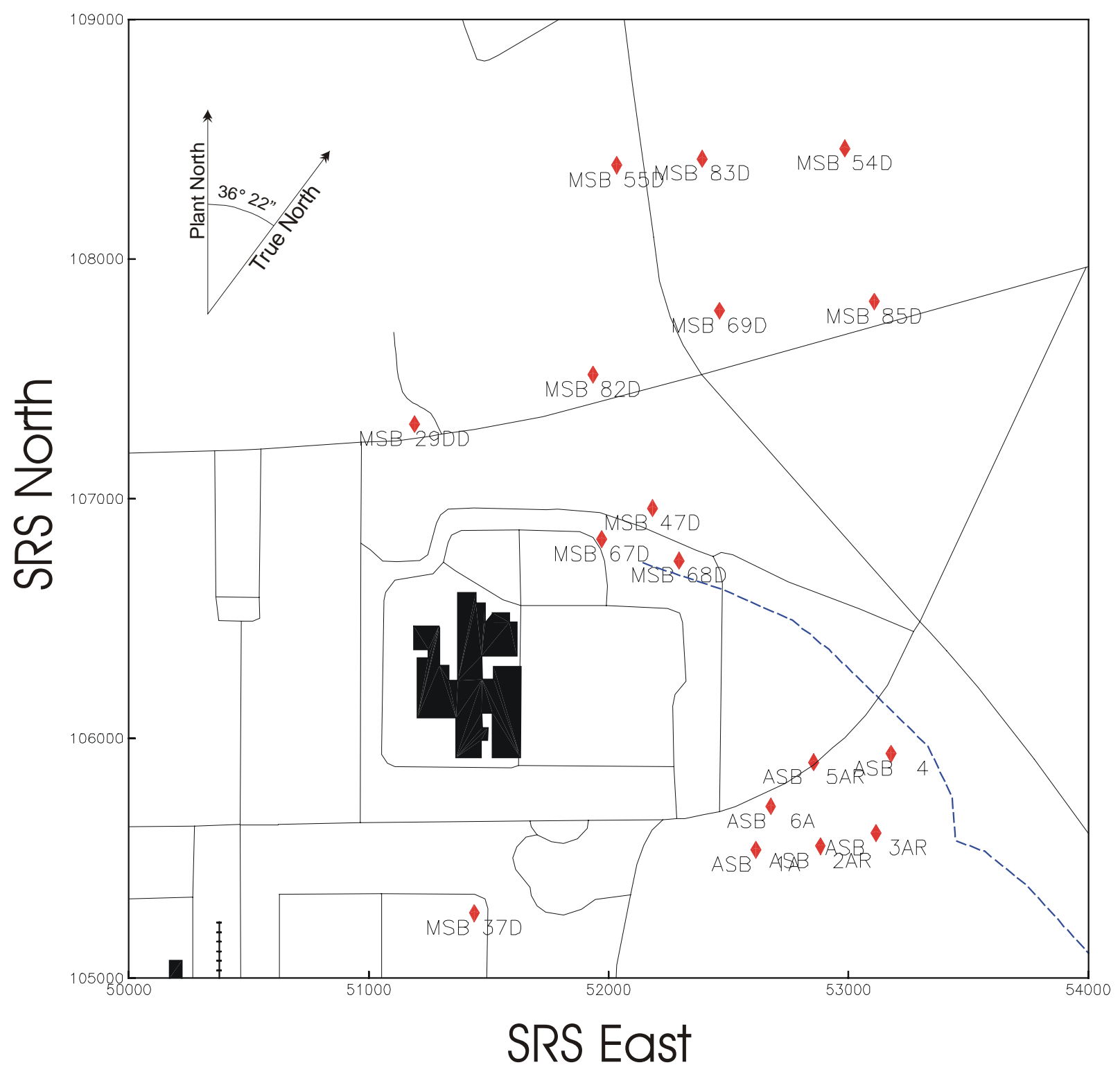

Figure 1. Location of the Northern Sector SVE Test Wells 


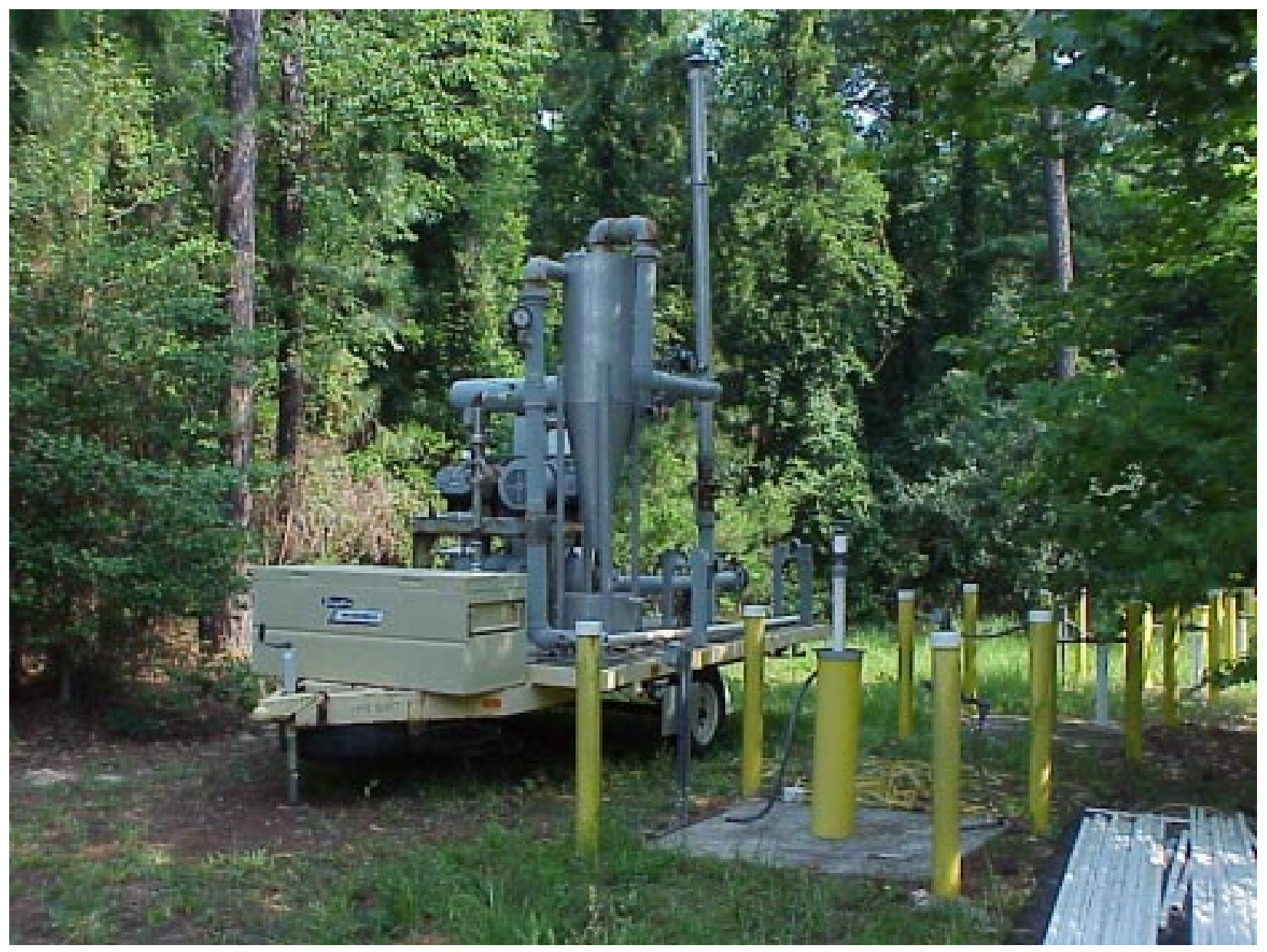

Figure 2. Trailer Mounted Portable SVE Unit Used in Northern Sector Testing 


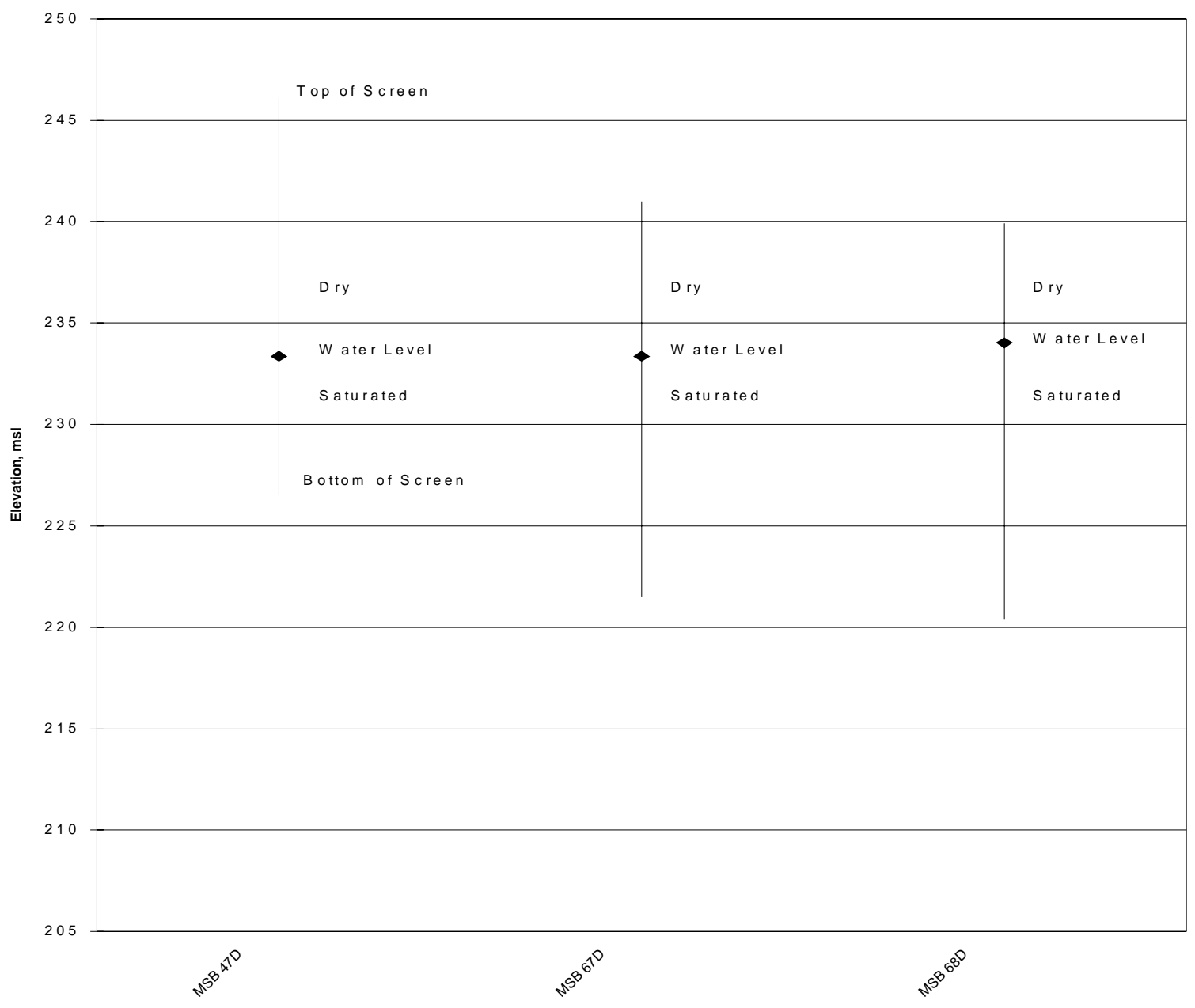

Figure 3. Well Construction Details for the Northern Sector Test Wells 


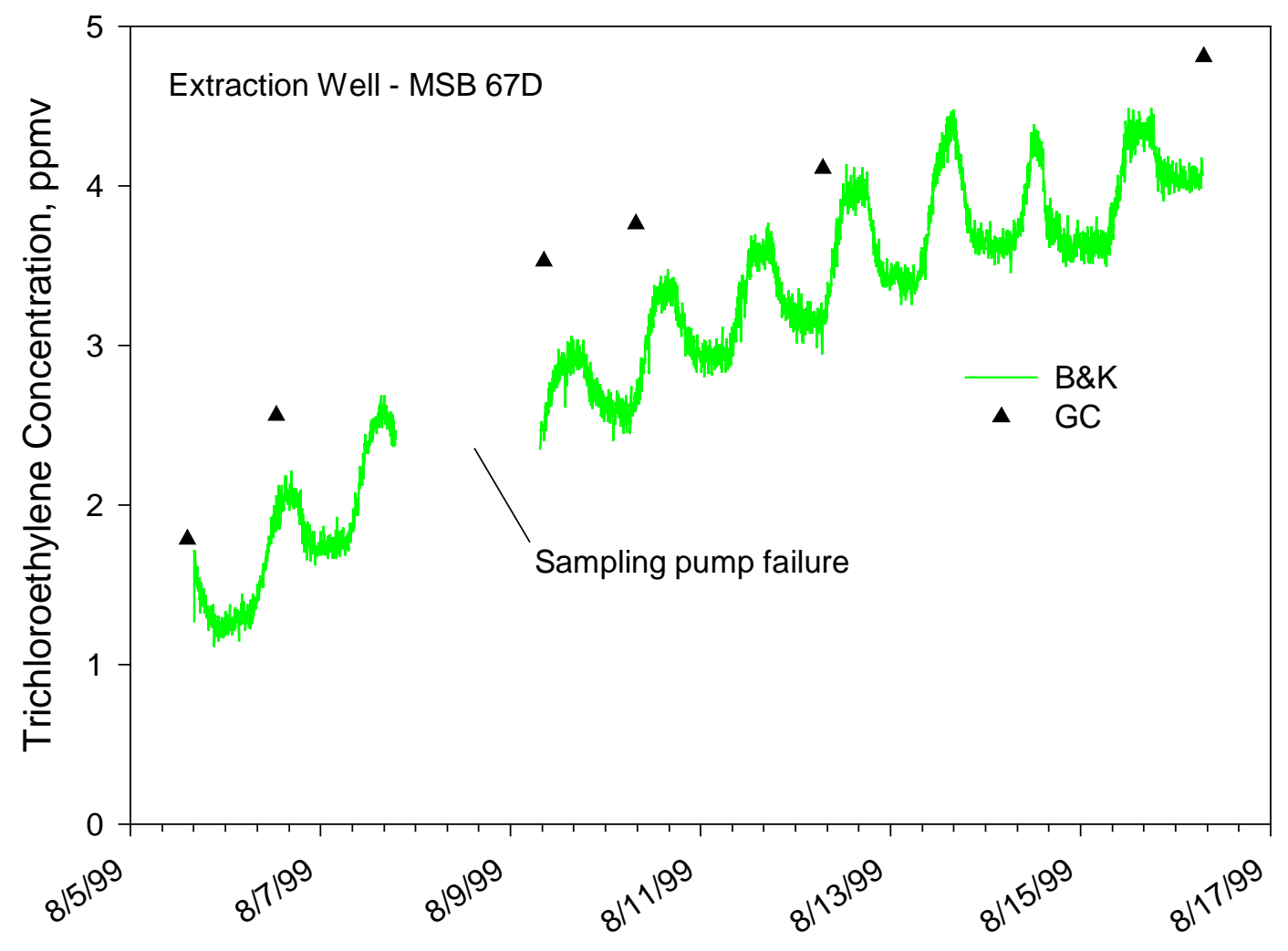

Figure 4. TCE Concentrations as a Function of Time for Test 3 on MSB 67D 


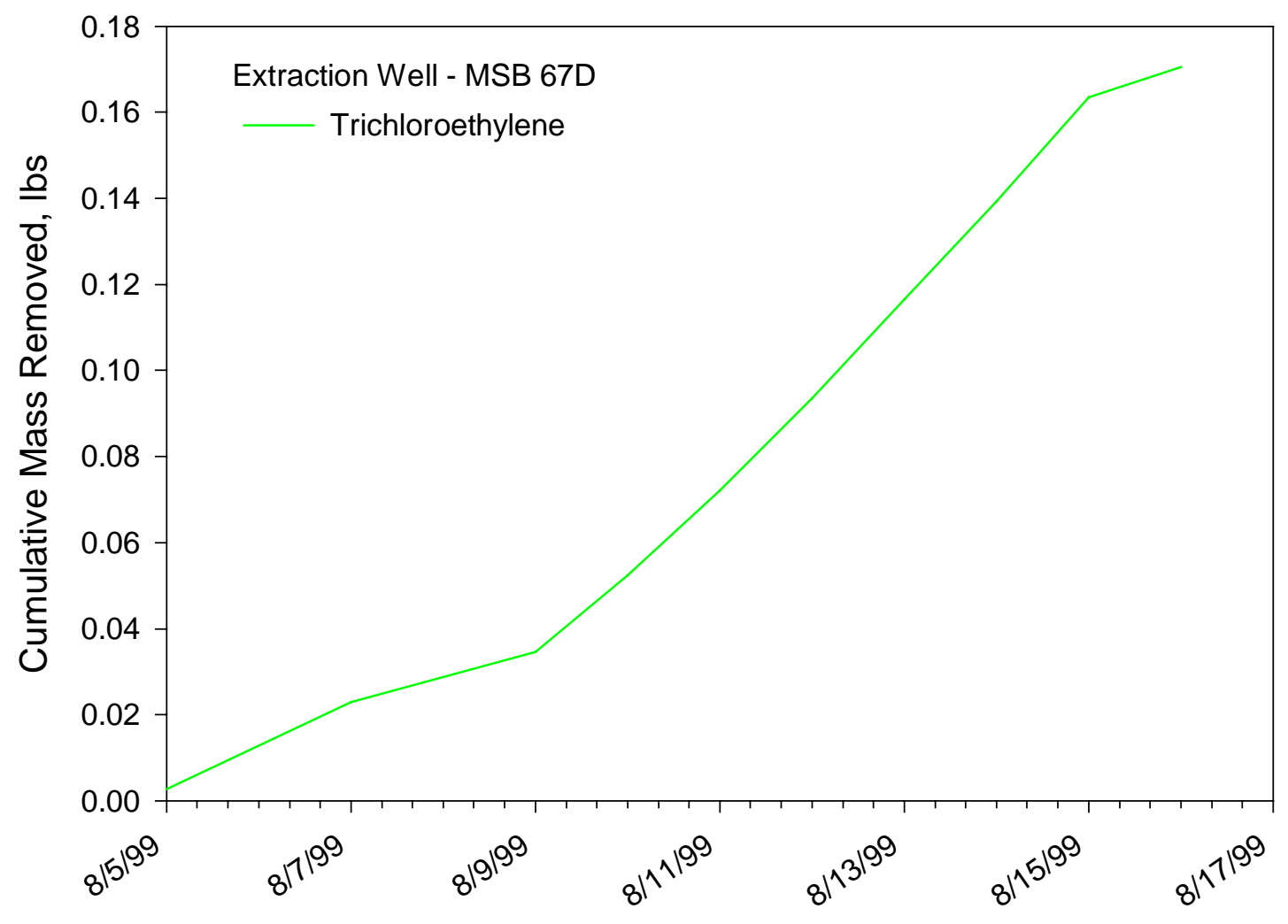

Figure 5. Cumulative TCE Mass Removed as a Function of Time for Test 3 on MSB 67D 


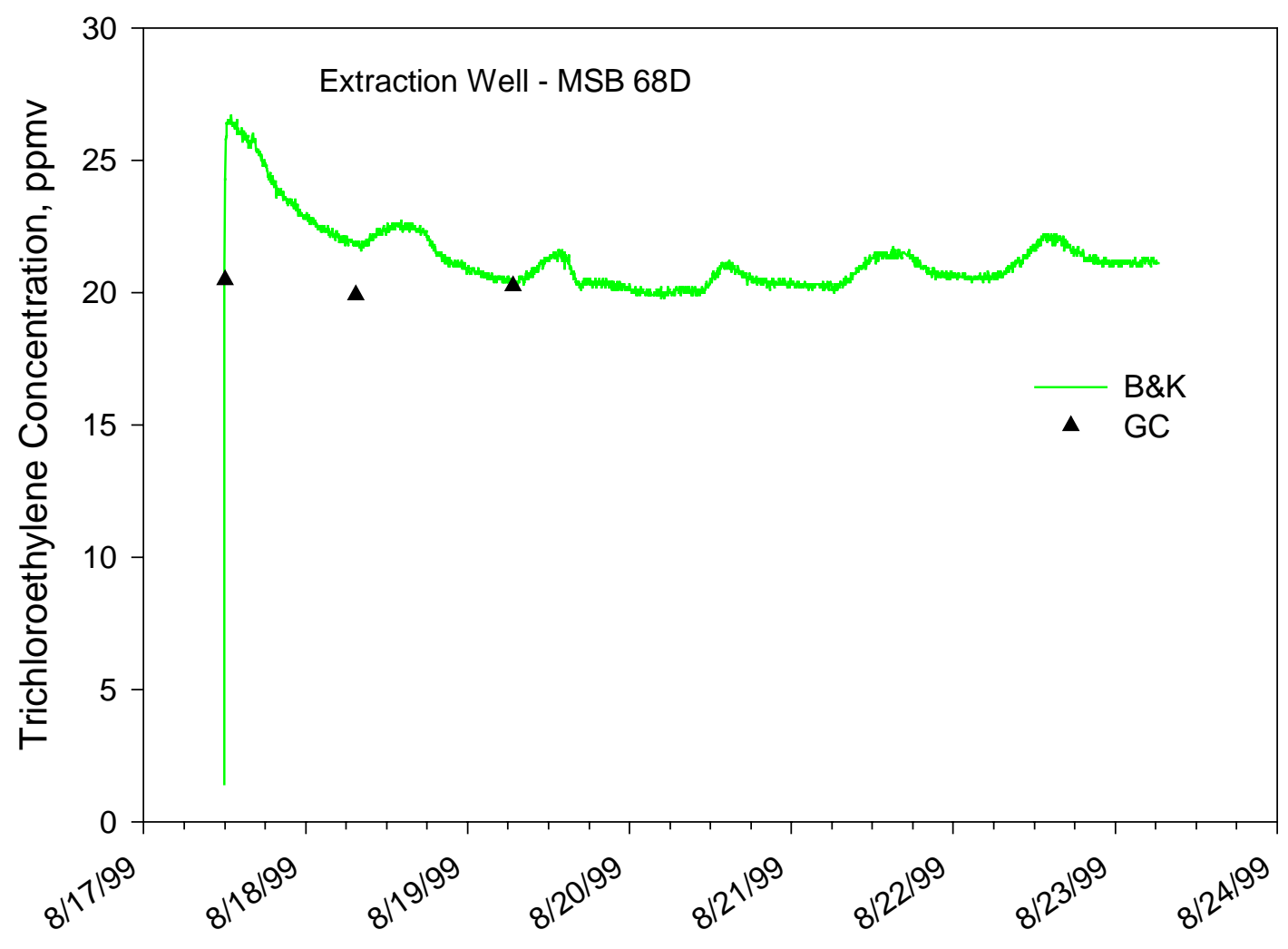

Figure 6. TCE Concentrations as a Function of Time for Test 4 on MSB 68D 


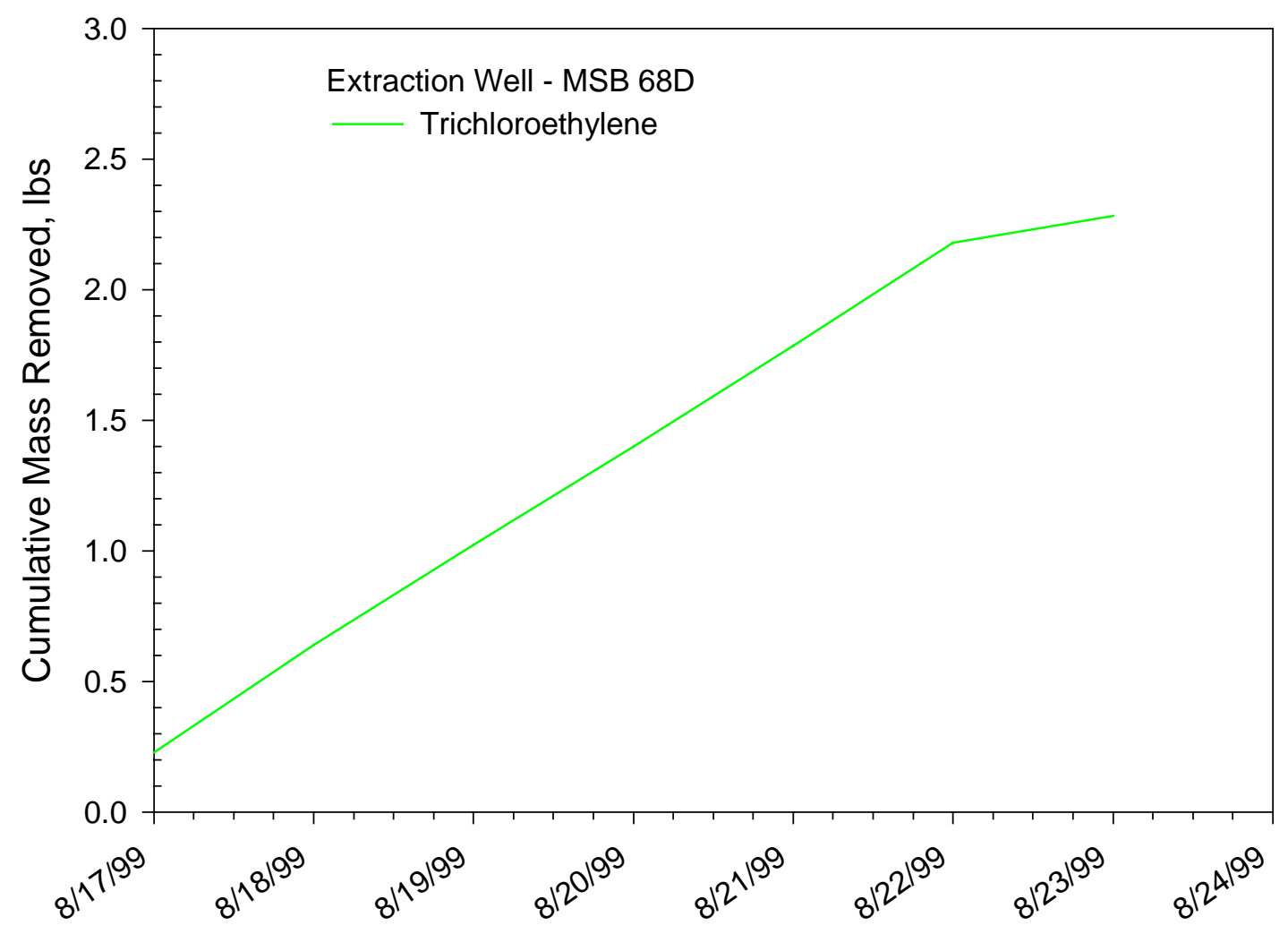

Figure 7. Cumulative TCE Mass Removed as a Function of Time for Test 4 on MSB 68D 


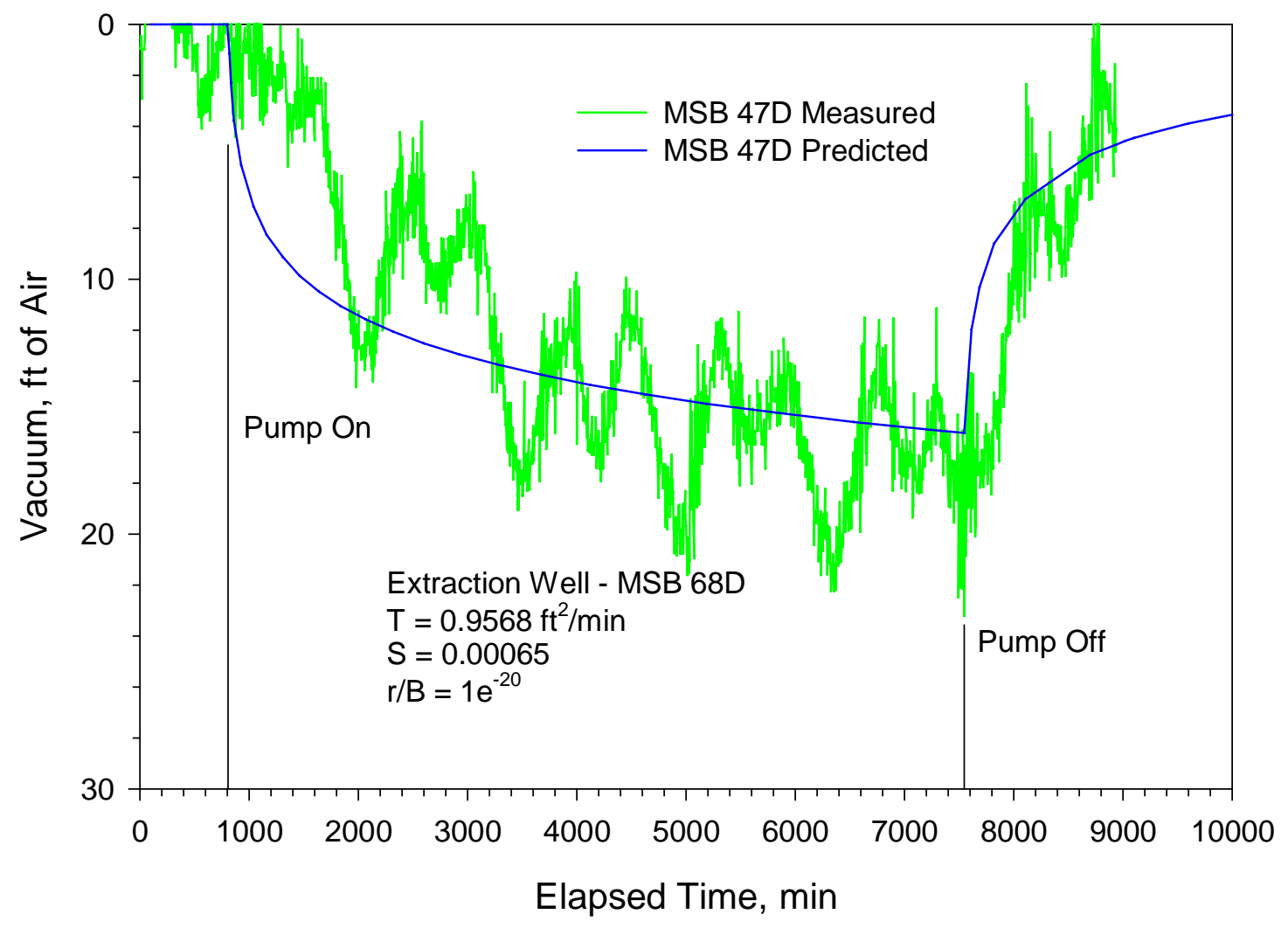

Figure 8. Vacuum Drawdown as Function of Time for MSB 68D. 
Table 1. Wells Utilized in the Northern Sector SVE Test

\begin{tabular}{lcclc}
\hline \hline Well ID & SRS North & SRS East & $\begin{array}{l}\text { Screen } \\
\text { Elevation } \\
\text { Top/Bottom } \\
(\mathrm{ft}, \mathrm{msl})\end{array}$ & $\begin{array}{c}\text { Zone }^{\mathbf{T C}} \\
(\mu \mathrm{g} / \mathrm{L})\end{array}$ \\
\hline MSB 47D & 106960 & 52184 & $246.1 / 226.5$ & $1.73(2 / 9 / 99)$ \\
MSB 67D & 106831 & 51972 & $241 / 221.5$ & $3030(3 / 16 / 99$ \\
MSB 68D & 106741 & 52294 & $239.9 / 220.4$ & $2190(1 / 30 / 95)$ \\
\hline
\end{tabular}

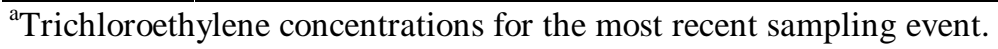

Table 2. Results of SVE Testing on the Northern Sector Wells

\begin{tabular}{llllllll} 
Test & Well & $\begin{array}{l}\text { Start } \\
\text { Date/Time }\end{array}$ & $\begin{array}{l}\text { Stop } \\
\text { Date/Time }\end{array}$ & $\begin{array}{l}\text { Duration } \\
\text { (Days) }\end{array}$ & $\begin{array}{l}\text { Flow } \\
\text { (scfm) }\end{array}$ & $\begin{array}{l}\text { TCE }^{\text {a }} \\
\text { (ppmv) }\end{array}$ & $\begin{array}{l}\text { Cumulative } \\
\text { TCE } \\
\text { (lbs) }\end{array}$ \\
\hline 1 & MSB 47D & $7 / 21 / 9913: 45$ & $7 / 28 / 998: 55$ & 6.80 & 18.5 & 0.0 & 0.00 \\
2 & MSB 68D & $7 / 29 / 9914: 00$ & $8 / 3 / 996: 26$ & 4.68 & 32.3 & 18.0 & 1.31 \\
3 & MSB 67D & $8 / 5 / 9912: 54$ & $8 / 16 / 997: 10$ & 10.76 & 12.6 & $1.1-4.5$ & 0.17 \\
4 & MSB 68D & $8 / 17 / 9911: 55$ & $8 / 23 / 997: 59$ & 5.84 & 38.6 & $19.8-20.7$ & 2.28 \\
\hline
\end{tabular}

${ }^{\mathrm{a}}$ Trichloroethylene 


\section{Appendix A}

\section{Drawdown Data}


Table A-1. Vadose Zone Differential Pressures and Barometric Pressure Recorded During SVE Testing on MSB 47D.

\begin{tabular}{|c|c|c|c|c|c|c|c|}
\hline Date/Time & $\begin{array}{l}\text { MSB 67D } \\
(\mathrm{mb})\end{array}$ & $\begin{array}{l}\text { MSB 68D } \\
(\mathrm{mb})\end{array}$ & $\begin{array}{l}\text { Barometric } \\
\text { Pressure } \\
(\mathrm{mb})\end{array}$ & Date/Time & $\begin{array}{l}\text { MSB 67D } \\
(\mathrm{mb})\end{array}$ & $\begin{array}{l}\text { MSB 68D } \\
(\mathrm{mb})\end{array}$ & $\begin{array}{l}\text { Barometric } \\
\text { Pressure } \\
(\mathrm{mb})\end{array}$ \\
\hline $7 / 20 / 990: 30$ & 1.52158 & 1.66780 & 1009.08 & $7 / 21 / 99$ 23:30 & 0.71849 & 0.69767 & 1007.10 \\
\hline 7/20/99 1:30 & 1.74116 & 1.93447 & 1009.06 & 7/22/99 0:30 & 0.76812 & 0.75898 & 1007.32 \\
\hline 7/20/99 2:30 & 2.08255 & 2.29769 & 1008.71 & 7/22/99 1:30 & 1.08093 & 1.10841 & 1007.20 \\
\hline 7/20/99 3:30 & 2.18181 & 2.42030 & 1008.29 & 7/22/99 2:30 & 1.43736 & 1.51761 & 1006.74 \\
\hline 7/20/99 4:30 & 1.95923 & 2.18581 & 1008.14 & 7/22/99 3:30 & 1.38924 & 1.46703 & 1006.28 \\
\hline 7/20/99 5:30 & 1.47797 & 1.63408 & 1008.39 & 7/22/99 4:30 & 1.23734 & 1.30304 & 1006.26 \\
\hline 7/20/99 6:30 & 1.02529 & 1.14825 & 1008.87 & 7/22/99 5:30 & 0.72450 & 0.72220 & 1006.47 \\
\hline 7/20/99 7:30 & 0.70796 & 0.77430 & 1009.30 & 7/22/99 6:30 & 0.29438 & 0.25323 & 1006.96 \\
\hline 7/20/99 8:30 & 0.50343 & 0.55361 & 1009.62 & 7/22/99 7:30 & -0.20342 & -0.30923 & 1007.46 \\
\hline 7/20/99 9:30 & 0.66435 & 0.70227 & 1009.71 & 7/22/99 8:30 & -0.25004 & -0.37820 & 1007.86 \\
\hline 7/20/99 10:30 & 0.65683 & 0.67162 & 1009.55 & 7/22/99 9:30 & -0.15680 & -0.30463 & 1007.91 \\
\hline 7/20/99 11:30 & 0.89745 & 0.93369 & 1009.47 & 7/22/99 10:30 & -0.09664 & -0.21728 & 1007.87 \\
\hline 7/20/99 12:30 & 1.25389 & 1.29232 & 1009.24 & 7/22/99 11:30 & -0.10867 & -0.20655 & 1007.81 \\
\hline 7/20/99 13:30 & 1.83591 & 1.92374 & 1008.86 & 7/22/99 12:30 & 0.35454 & 0.28541 & 1007.69 \\
\hline 7/20/99 14:30 & 2.49463 & 2.66551 & 1008.21 & 7/22/99 13:30 & 0.68239 & 0.66549 & 1007.19 \\
\hline 7/20/99 15:30 & 2.81045 & 3.00881 & 1007.45 & 7/22/99 14:30 & 1.34863 & 1.40420 & 1006.74 \\
\hline 7/20/99 16:30 & 3.06612 & 3.30307 & 1007.06 & 7/22/99 15:30 & 1.52158 & 1.56818 & 1006.46 \\
\hline 7/20/99 17:30 & 3.24358 & 3.48084 & 1006.73 & 7/22/99 16:30 & 2.04646 & 2.16436 & 1005.94 \\
\hline 7/20/99 18:30 & 2.86459 & 3.07931 & 1006.47 & 7/22/99 17:30 & 2.16527 & 2.28543 & 1005.19 \\
\hline 7/20/99 19:30 & 2.57584 & 2.76206 & 1006.78 & 7/22/99 18:30 & 1.65092 & 1.71684 & 1005.13 \\
\hline 7/20/99 20:30 & 2.39086 & 2.58122 & 1006.99 & 7/22/99 19:30 & 1.71108 & 1.80113 & 1005.49 \\
\hline 7/20/99 21:30 & 1.48850 & 1.60190 & 1007.11 & 7/22/99 20:30 & 1.50504 & 1.58504 & 1005.37 \\
\hline 7/20/99 22:30 & 1.23885 & 1.33216 & 1007.93 & 7/22/99 21:30 & 1.28697 & 1.34289 & 1005.52 \\
\hline 7/20/99 23:30 & 1.03281 & 1.09002 & 1008.09 & 7/22/99 22:30 & 1.32006 & 1.38580 & 1005.62 \\
\hline 7/21/99 0:30 & 1.40127 & 1.51607 & 1008.21 & 7/22/99 23:30 & 0.89294 & 0.92143 & 1005.57 \\
\hline 7/21/99 1:30 & 1.60881 & 1.75209 & 1007.76 & 7/23/99 0:30 & 0.92453 & 0.94442 & 1005.99 \\
\hline 7/21/99 2:30 & 1.54866 & 1.69232 & 1007.57 & 7/23/99 1:30 & 1.32758 & 1.38887 & 1005.85 \\
\hline 7/21/99 3:30 & 1.57723 & 1.71684 & 1007.47 & 7/23/99 2:30 & 1.52309 & 1.61263 & 1005.34 \\
\hline 7/21/99 4:30 & 1.31254 & 1.44557 & 1007.43 & 7/23/99 3:30 & 1.89005 & 2.01416 & 1005.06 \\
\hline 7/21/99 5:30 & 0.85083 & 0.94749 & 1007.70 & 7/23/99 4:30 & 1.79831 & 1.92068 & 1004.54 \\
\hline 7/21/99 6:30 & 0.41921 & 0.46625 & 1008.11 & 7/23/99 5:30 & 1.71559 & 1.84558 & 1004.61 \\
\hline 7/21/99 7:30 & 0.01615 & 0.02027 & 1008.53 & 7/23/99 6:30 & 1.35164 & 1.42872 & 1004.58 \\
\hline 7/21/99 8:30 & -0.27260 & -0.31383 & 1008.94 & 7/23/99 7:30 & 0.84933 & 0.86013 & 1005.05 \\
\hline 7/21/99 9:30 & -0.30870 & -0.37360 & 1009.24 & 7/23/99 8:30 & 0.44928 & 0.40342 & 1005.49 \\
\hline 7/21/99 10:30 & -0.40194 & -0.47475 & 1009.26 & 7/23/99 9:30 & 0.48688 & 0.41415 & 1005.90 \\
\hline 7/21/99 11:30 & -0.29817 & -0.38739 & 1009.41 & 7/23/99 10:30 & 0.52899 & 0.45399 & 1005.84 \\
\hline 7/21/99 12:30 & 0.18760 & 0.14135 & 1009.25 & 7/23/99 11:30 & 0.84331 & 0.79423 & 1005.75 \\
\hline 7/21/99 13:30 & 0.73353 & 0.75131 & 1008.79 & 7/23/99 12:30 & 1.36066 & 1.35822 & 1005.44 \\
\hline 7/21/99 14:30 & 1.25389 & 1.25707 & 1008.14 & 7/23/99 13:30 & 1.99382 & 2.03409 & 1004.81 \\
\hline 7/21/99 15:30 & 1.72762 & 1.76435 & 1007.66 & 7/23/99 14:30 & 2.33070 & 2.42183 & 1004.13 \\
\hline 7/21/99 16:30 & 2.09157 & 2.15823 & 1007.11 & 7/23/99 15:30 & 2.83151 & 2.97049 & 1003.64 \\
\hline 7/21/99 17:30 & 2.02540 & 2.09539 & 1006.52 & 7/23/99 16:30 & 3.19245 & 3.34904 & 1003.06 \\
\hline 7/21/99 18:30 & 1.95772 & 2.00650 & 1006.53 & 7/23/99 17:30 & 3.56542 & 3.77510 & 1002.61 \\
\hline 7/21/99 19:30 & 1.55918 & 1.59270 & 1006.50 & 7/23/99 18:30 & 3.53535 & 3.73525 & 1002.15 \\
\hline 7/21/99 20:30 & 0.98167 & 0.95975 & 1006.80 & 7/23/99 19:30 & 3.01047 & 3.16053 & 1002.14 \\
\hline 7/21/99 21:30 & 0.81925 & 0.81875 & 1007.30 & 7/23/99 20:30 & 2.16677 & 2.24252 & 1002.55 \\
\hline 7/21/99 22:30 & 0.98919 & 0.99653 & 1007.30 & 7/23/99 21:30 & 1.33359 & 1.32757 & 1003.44 \\
\hline
\end{tabular}


Table A-1. Continued.

\begin{tabular}{|c|c|c|c|c|c|c|c|}
\hline Date/Time & $\begin{array}{l}\text { MSB 67D } \\
(\mathrm{mb})\end{array}$ & $\begin{array}{l}\text { MSB 68D } \\
(\mathrm{mb})\end{array}$ & $\begin{array}{l}\text { Barometric } \\
\text { Pressure } \\
(\mathrm{mb})\end{array}$ & Date/Time & $\begin{array}{l}\text { MSB 67D } \\
(\mathrm{mb})\end{array}$ & $\begin{array}{l}\text { MSB 68D } \\
(\mathrm{mb})\end{array}$ & $\begin{array}{l}=: \text { Barometric } \\
\text { Pressure } \\
(\mathrm{mb})\end{array}$ \\
\hline $7 / 23 / 99$ 22:30 & 0.80271 & 0.74825 & 1004.17 & $7 / 25 / 99$ 21:30 & -0.09664 & -0.16210 & 1002.68 \\
\hline 7/23/99 23:30 & 0.82978 & 0.80649 & 1004.53 & 7/25/99 22:30 & -0.16883 & -0.24333 & 1003.11 \\
\hline 7/24/99 0:30 & 1.33209 & 1.37508 & 1004.38 & 7/25/99 23:30 & -0.11770 & -0.18356 & 1003.11 \\
\hline 7/24/99 1:30 & 1.89306 & 1.99577 & 1003.69 & 7/26/99 0:30 & -0.17485 & -0.22494 & 1003.09 \\
\hline 7/24/99 2:30 & 2.10361 & 2.24405 & 1003.09 & 7/26/99 1:30 & 0.00262 & -0.01804 & 1003.14 \\
\hline 7/24/99 3:30 & 1.95020 & 2.07240 & 1002.85 & 7/26/99 2:30 & -0.00189 & -0.03643 & 1002.86 \\
\hline 7/24/99 4:30 & 1.92915 & 2.02949 & 1002.96 & 7/26/99 3:30 & 0.02668 & 0.01414 & 1002.86 \\
\hline 7/24/99 5:30 & 1.77124 & 1.86857 & 1002.85 & 7/26/99 4:30 & 0.06578 & 0.04020 & 1002.84 \\
\hline 7/24/99 6:30 & 1.41029 & 1.47929 & 1002.91 & 7/26/99 5:30 & 0.04623 & 0.03560 & 1002.76 \\
\hline 7/24/99 7:30 & 0.68239 & 0.66243 & 1003.35 & 7/26/99 6:30 & -0.33276 & -0.38433 & 1002.70 \\
\hline 7/24/99 8:30 & 0.15451 & 0.06932 & 1004.07 & 7/26/99 7:30 & -0.38376 & -0.48711 & 1003.22 \\
\hline 7/24/99 9:30 & -0.00641 & -0.12226 & 1004.52 & 7/26/99 8:30 & -0.40576 & -0.45687 & 1003.58 \\
\hline 7/24/99 10:30 & 0.18459 & 0.06625 & 1004.65 & 7/26/99 9:30 & -0.43474 & -0.50177 & 1003.83 \\
\hline 7/24/99 11:30 & 0.30340 & 0.19499 & 1004.45 & 7/26/99 10:30 & -0.47276 & -0.54544 & 1004.02 \\
\hline 7/24/99 12:30 & 0.73052 & 0.64250 & 1004.29 & 7/26/99 11:30 & -0.37860 & -0.44826 & 1004.05 \\
\hline 7/24/99 13:30 & 1.70206 & 1.70611 & 1003.72 & 7/26/99 12:30 & -0.26875 & -0.33262 & 1003.84 \\
\hline 7/24/99 14:30 & 2.67209 & 2.76973 & 1002.68 & 7/26/99 13:30 & -0.03516 & -0.07490 & 1003.52 \\
\hline 7/24/99 15:30 & 3.21952 & 3.37510 & 1001.59 & 7/26/99 14:30 & 0.16583 & 0.15514 & 1002.91 \\
\hline 7/24/99 16:30 & 3.49173 & 3.69387 & 1000.99 & 7/26/99 15:30 & 0.35475 & 0.36735 & 1002.45 \\
\hline 7/24/99 17:30 & 3.45263 & 3.63564 & 1000.61 & 7/26/99 16:30 & 0.51410 & 0.53649 & 1001.88 \\
\hline 7/24/99 18:30 & 2.59689 & 2.70536 & 1000.64 & 7/26/99 17:30 & 0.63542 & 0.66812 & 1001.42 \\
\hline 7/24/99 19:30 & 1.48549 & 1.50535 & 1001.43 & 7/26/99 18:30 & 0.65835 & 0.66997 & 1000.97 \\
\hline $7 / 24 / 9920: 30$ & 0.23723 & 0.18119 & 1002.25 & 7/26/99 19:30 & 0.40666 & 0.41225 & 1001.05 \\
\hline 7/24/99 21:30 & 0.24475 & 0.17200 & 1003.54 & 7/26/99 20:30 & 0.17609 & 0.17236 & 1001.61 \\
\hline 7/24/99 22:30 & -0.12822 & -0.22341 & 1003.63 & 7/26/99 21:30 & -0.04603 & -0.06506 & 1002.15 \\
\hline 7/24/99 23:30 & -0.28915 & -0.41192 & 1003.89 & 7/26/99 22:30 & -0.16795 & -0.20530 & 1002.63 \\
\hline 7/25/99 0:30 & -0.15530 & -0.24793 & 1003.83 & 7/26/99 23:30 & -0.17218 & -0.20161 & 1002.83 \\
\hline 7/25/99 1:30 & 0.30641 & 0.26855 & 1003.72 & 7/27/99 0:30 & -0.11303 & -0.13272 & 1002.82 \\
\hline 7/25/99 2:30 & 0.45981 & 0.43101 & 1003.28 & 7/27/99 1:30 & 0.01010 & 0.00629 & 1002.60 \\
\hline 7/25/99 3:30 & 0.65382 & 0.66549 & 1002.96 & 7/27/99 2:30 & 0.01010 & 0.00875 & 1002.31 \\
\hline 7/25/99 4:30 & 0.42522 & 0.41261 & 1002.81 & 7/27/99 3:30 & -0.05629 & -0.07059 & 1002.31 \\
\hline 7/25/99 5:30 & 0.12143 & 0.09077 & 1003.01 & 7/27/99 4:30 & -0.16192 & -0.17762 & 1002.44 \\
\hline 7/25/99 6:30 & -0.28012 & -0.35521 & 1003.31 & 7/27/99 5:30 & -0.32971 & -0.36337 & 1002.73 \\
\hline 7/25/99 7:30 & -0.58091 & -0.68778 & 1003.68 & 7/27/99 6:30 & -0.57054 & -0.63340 & 1003.12 \\
\hline 7/25/99 8:30 & -0.63354 & -0.74755 & 1004.02 & 7/27/99 7:30 & -0.81801 & -0.90895 & 1003.84 \\
\hline 7/25/99 9:30 & -0.71025 & -0.88395 & 1004.06 & 7/27/99 8:30 & -0.93873 & -1.04058 & 1004.47 \\
\hline 7/25/99 10:30 & -0.89372 & -1.06633 & 1004.25 & 7/27/99 9:30 & -0.90855 & -1.01044 & 1004.79 \\
\hline 7/25/99 11:30 & -0.59745 & -0.74449 & 1004.30 & 7/27/99 10:30 & -0.91157 & -1.02766 & 1004.78 \\
\hline 7/25/99 12:30 & -0.31321 & -0.42418 & 1004.00 & 7/27/99 11:30 & -0.75705 & -0.86344 & 1004.86 \\
\hline 7/25/99 13:30 & 0.18910 & 0.13368 & 1003.65 & 7/27/99 12:30 & -0.68643 & -0.77794 & 1004.51 \\
\hline 7/25/99 14:30 & 0.68690 & 0.66089 & 1003.09 & 7/27/99 13:30 & -0.44560 & -0.50546 & 1004.37 \\
\hline 7/25/99 15:30 & 1.26441 & 1.31990 & 1002.60 & 7/27/99 14:30 & -0.31161 & -0.35907 & 1003.75 \\
\hline 7/25/99 16:30 & 1.52459 & 1.57584 & 1001.97 & 7/27/99 15:30 & -0.09130 & -0.12964 & 1003.40 \\
\hline 7/25/99 17:30 & 1.37270 & 1.39500 & 1001.72 & 7/27/99 16:30 & -0.00921 & -0.03738 & 1002.92 \\
\hline 7/25/99 18:30 & 1.15463 & 1.14519 & 1001.84 & 7/27/99 17:30 & -0.01887 & -0.04599 & 1002.71 \\
\hline 7/25/99 19:30 & 0.73503 & 0.71147 & 1002.08 & 7/27/99 18:30 & -0.02189 & -0.05891 & 1002.75 \\
\hline 7/25/99 20:30 & 0.38913 & 0.36204 & 1002.35 & 7/27/99 19:30 & -0.16735 & -0.20468 & 1002.73 \\
\hline
\end{tabular}


Table A-1. Continued.

\begin{tabular}{|c|c|c|c|c|c|c|c|}
\hline Date/Time & $\begin{array}{l}\text { MSB 67D } \\
(\mathrm{mb})\end{array}$ & $\begin{array}{l}\text { MSB 68D } \\
(\mathrm{mb})\end{array}$ & $\begin{array}{l}\text { Barometric } \\
\text { Pressure } \\
(\mathrm{mb})\end{array}$ & Date/Time & $\begin{array}{l}\text { MSB 67D } \\
(\mathrm{mb})\end{array}$ & $\begin{array}{l}\text { MSB 68D } \\
(\mathrm{mb})\end{array}$ & $\begin{array}{l}\text { Barometric } \\
\text { Pressure } \\
(\mathrm{mb})\end{array}$ \\
\hline $7 / 27 / 9920: 30$ & -0.37559 & -0.43042 & 1003.06 & 7/29/99 19:30 & 0.97704 & 1.02425 & 998.50 \\
\hline 7/27/99 21:30 & -0.56330 & -0.63278 & 1003.51 & 7/29/99 20:30 & 0.94747 & 0.99596 & 998.73 \\
\hline 7/27/99 22:30 & -0.64901 & -0.71951 & 1004.02 & 7/29/99 21:30 & 0.81710 & 0.85695 & 999.05 \\
\hline 7/27/99 23:30 & -0.59408 & -0.65369 & 1004.11 & 7/29/99 22:30 & 0.85331 & 0.90124 & 999.11 \\
\hline 7/28/99 0:30 & -0.48725 & -0.53252 & 1004.00 & 7/29/99 23:30 & 0.73984 & 0.75915 & 998.92 \\
\hline 7/28/99 1:30 & -0.40999 & -0.44580 & 1003.79 & 7/30/99 0:30 & 0.75432 & 0.78376 & 999.08 \\
\hline 7/28/99 2:30 & -0.33273 & -0.35968 & 1003.53 & 7/30/99 1:30 & 0.80321 & 0.83727 & 998.87 \\
\hline 7/28/99 3:30 & -0.39430 & -0.42119 & 1003.45 & 7/30/99 2:30 & 0.76398 & 0.79606 & 998.66 \\
\hline 7/28/99 4:30 & -0.39550 & -0.42611 & 1003.53 & 7/30/99 3:30 & 0.78873 & 0.81882 & 998.63 \\
\hline 7/28/99 5:30 & -0.52709 & -0.57066 & 1003.59 & 7/30/99 4:30 & 0.73380 & 0.75977 & 998.50 \\
\hline 7/28/99 6:30 & -0.70333 & -0.76441 & 1003.94 & 7/30/99 5:30 & 0.49176 & 0.48114 & 998.57 \\
\hline 7/28/99 7:30 & -0.85543 & -0.93663 & 1004.44 & 7/30/99 6:30 & 0.20506 & 0.17052 & 999.13 \\
\hline 7/28/99 8:30 & -0.95684 & -1.04796 & 1004.88 & 7/30/99 7:30 & 0.09702 & 0.04812 & 999.79 \\
\hline 7/28/99 9:30 & -0.99788 & -1.08118 & 1005.19 & 7/30/99 8:30 & -0.07983 & -0.15855 & 999.98 \\
\hline 7/28/99 10:30 & -1.06186 & -1.14145 & 1005.48 & 7/30/99 9:30 & -0.25487 & -0.36214 & 1000.43 \\
\hline 7/28/99 11:30 & -0.92424 & -0.98276 & 1005.75 & 7/30/99 10:30 & -0.21564 & -0.33200 & 1000.86 \\
\hline 7/28/99 12:30 & -0.70092 & -0.74288 & 1005.44 & 7/30/99 11:30 & -0.11786 & -0.22929 & 1000.74 \\
\hline 7/28/99 13:30 & -0.41723 & -0.42181 & 1004.96 & 7/30/99 12:30 & -0.04543 & -0.15486 & 1000.53 \\
\hline 7/28/99 14:30 & -0.14321 & -0.11734 & 1004.23 & 7/30/99 13:30 & 0.22136 & 0.14161 & 1000.30 \\
\hline 7/28/99 15:30 & 0.13987 & 0.19328 & 1003.62 & 7/30/99 14:30 & 0.39760 & 0.33475 & 999.50 \\
\hline 7/28/99 16:30 & 0.39760 & 0.48237 & 1002.93 & 7/30/99 15:30 & 0.55091 & 0.51189 & 998.96 \\
\hline 7/28/99 17:30 & 0.51470 & 0.59677 & 1002.26 & 7/30/99 16:30 & 0.68129 & 0.65336 & 998.54 \\
\hline 7/28/99 18:30 & 0.48331 & 0.55002 & 1001.98 & 7/30/99 17:30 & 0.79174 & 0.75854 & 998.15 \\
\hline 7/28/99 19:30 & 0.31371 & 0.36611 & 1002.14 & 7/30/99 18:30 & 0.85391 & 0.83173 & 997.85 \\
\hline 7/28/99 20:30 & 0.22558 & 0.27877 & 1002.44 & 7/30/99 19:30 & 0.66016 & 0.63983 & 997.65 \\
\hline 7/28/99 21:30 & 0.15979 & 0.21234 & 1002.62 & 7/30/99 20:30 & 0.32457 & 0.26278 & 998.05 \\
\hline 7/28/99 22:30 & 0.15617 & 0.21726 & 1002.77 & 7/30/99 21:30 & 0.03666 & -0.03738 & 998.84 \\
\hline 7/28/99 23:30 & 0.20023 & 0.26278 & 1002.71 & 7/30/99 22:30 & 0.06503 & -0.01093 & 999.42 \\
\hline 7/29/99 0:30 & 0.15376 & 0.21788 & 1002.59 & 7/30/99 23:27 & 0.05960 & -0.00909 & 999.29 \\
\hline 7/29/99 1:30 & 0.36260 & 0.45161 & 1002.55 & & & & \\
\hline 7/29/99 2:30 & 0.54729 & 0.65705 & 1001.96 & & & & \\
\hline 7/29/99 3:30 & 0.55514 & 0.66197 & 1001.48 & & & & \\
\hline 7/29/99 4:30 & 0.55454 & 0.66074 & 1001.41 & & & & \\
\hline 7/29/99 5:30 & 0.35596 & 0.43500 & 1001.41 & & & & \\
\hline 7/29/99 6:30 & 0.29439 & 0.36981 & 1001.93 & & & & \\
\hline 7/29/99 7:30 & 0.27266 & 0.34766 & 1002.04 & & & & \\
\hline 7/29/99 8:30 & 0.25757 & 0.25663 & 1002.11 & & & & \\
\hline 7/29/99 9:30 & 0.33302 & 0.18836 & 1002.10 & & & & \\
\hline 7/29/99 10:30 & 0.44649 & 0.47683 & 1001.93 & & & & \\
\hline 7/29/99 11:30 & 0.63481 & 0.68104 & 1001.60 & & & & \\
\hline 7/29/99 12:30 & 0.79174 & 0.85265 & 1001.11 & & & & \\
\hline 7/29/99 13:30 & 0.98127 & 1.05747 & 1000.67 & & & & \\
\hline 7/29/99 14:30 & 1.19071 & 1.26291 & 1000.13 & & & & \\
\hline 7/29/99 15:30 & 1.36515 & 1.43144 & 999.47 & & & & \\
\hline 7/29/99 16:30 & 1.54140 & 1.59751 & 998.76 & & & & \\
\hline 7/29/99 17:30 & 1.54019 & 1.59874 & 998.12 & & & & \\
\hline 7/29/99 18:30 & 1.20761 & 1.26844 & 998.09 & & & & \\
\hline
\end{tabular}


Table A-2. Vadose Zone Differential Pressures and Barometric Pressure Recorded During SVE Testing on MSB 67D.

\begin{tabular}{|c|c|c|c|c|c|c|c|}
\hline Date/Time & $\begin{array}{l}\text { MSB 47D } \\
(\mathrm{mb})\end{array}$ & $\begin{array}{l}\text { MSB 68D } \\
(\mathrm{mb})\end{array}$ & $\begin{array}{l}\text { Barometric } \\
\text { Pressure } \\
(\mathrm{mb})\end{array}$ & Date/Time & $\begin{array}{l}\text { MSB 47D } \\
(\mathrm{mb})\end{array}$ & $\begin{array}{l}\text { MSB 68D } \\
(\mathrm{mb})\end{array}$ & $\begin{array}{l}=: \text { Barometric } \\
\text { Pressure } \\
(\mathrm{mb})\end{array}$ \\
\hline $8 / 4 / 99$ 7:30 & -0.97644 & -1.88166 & 1004.32 & $8 / 6 / 996: 30$ & -1.48778 & -1.79737 & 1002.94 \\
\hline 8/4/99 8:30 & -1.41108 & -1.77438 & 1004.57 & 8/6/99 7:30 & -1.89684 & -2.28013 & 1003.23 \\
\hline 8/4/99 9:30 & -1.38852 & -1.78664 & 1004.47 & 8/6/99 8:30 & -2.08634 & -2.46558 & 1003.60 \\
\hline 8/4/99 10:30 & -1.20053 & -1.55675 & 1004.50 & 8/6/99 9:30 & -2.09236 & -2.52994 & 1003.84 \\
\hline 8/4/99 11:30 & -0.71476 & -1.06633 & 1004.40 & 8/6/99 10:30 & -2.00814 & -2.45178 & 1003.91 \\
\hline 8/4/99 12:30 & -0.17184 & -0.45330 & 1003.90 & 8/6/99 11:30 & -1.76600 & -2.20504 & 1003.95 \\
\hline 8/4/99 13:30 & 0.42071 & 0.19652 & 1003.30 & 8/6/99 12:30 & -1.39453 & -1.81729 & 1003.72 \\
\hline 8/4/99 14:30 & 1.33961 & 1.21262 & 1002.64 & 8/6/99 13:30 & -0.98697 & -1.34679 & 1003.40 \\
\hline 8/4/99 15:30 & 1.99833 & 1.91301 & 1001.60 & 8/6/99 14:30 & -0.36735 & -0.68472 & 1002.96 \\
\hline 8/4/99 16:30 & 2.21339 & 2.13064 & 1000.91 & 8/6/99 15:30 & 0.07029 & -0.19889 & 1002.41 \\
\hline 8/4/99 17:30 & 2.20738 & 2.16436 & 1000.71 & 8/6/99 16:30 & 0.15151 & -0.13145 & 1002.04 \\
\hline 8/4/99 18:30 & 2.20738 & 2.14443 & 1000.64 & 8/6/99 17:30 & 0.19211 & -0.08088 & 1001.96 \\
\hline 8/4/99 19:30 & 1.67047 & 1.61876 & 1000.70 & 8/6/99 18:30 & -0.05904 & -0.34601 & 1001.89 \\
\hline 8/4/99 20:30 & 1.16365 & 1.06703 & 1001.26 & 8/6/99 19:30 & -0.59595 & -0.91000 & 1002.16 \\
\hline 8/4/99 21:30 & 0.58013 & 0.46012 & 1001.77 & 8/6/99 20:30 & -1.42160 & -1.81423 & 1002.75 \\
\hline 8/4/99 22:30 & 0.65382 & 0.56894 & 1002.18 & & & -2.56673 & 1003.67 \\
\hline 8/4/99 23:30 & 0.66435 & 0.58733 & 1002.03 & 8/6/99 22:30 & -2.22169 & -2.65408 & 1004.23 \\
\hline 8/5/99 0:30 & 0.81173 & 0.77124 & 1001.95 & 8/6/99 23:30 & -2.37058 & -2.83493 & 1004.32 \\
\hline 8/5/99 1:30 & 0.84632 & 0.82641 & 1001.73 & 8/7/99 0:30 & -2.05927 & -2.47784 & 1004.47 \\
\hline 8/5/99 2:30 & 1.01777 & 1.03791 & 1001.62 & 8/7/99 1:30 & -1.65020 & -2.01959 & 1004.08 \\
\hline 8/5/99 3:30 & 1.01326 & & & 8/7/99 2:30 & & & \\
\hline 8/5/99 4:30 & 1.02378 & 1.03025 & 1001.40 & 8/7/99 3:30 & -1.92542 & -2.34910 & 1003.86 \\
\hline 8/5/99 5:30 & 0.66735 & 0.64403 & 1001.47 & 8/7/99 4:30 & -2.12544 & -2.56979 & 1004.16 \\
\hline 8/5/99 6:30 & 0.39213 & 0.32679 & 1001.79 & 8/7/99 5:30 & -2.55406 & -3.03416 & 1004.43 \\
\hline 8/5/99 7:30 & 0.13195 & 0.02334 & 1002.02 & 8/7/99 6:30 & -2.90448 & -3.41118 & 1004.95 \\
\hline 8/5/99 8:30 & 0.00412 & -0.14984 & 1002.32 & 8/7/99 7:30 & -3.17518 & -3.68091 & 1005.32 \\
\hline 8/5/99 9:30 & 0.00562 & -0.17436 & 1002.45 & 8/7/99 8:30 & -3.39325 & -3.97211 & 1005.75 \\
\hline 8/5/99 10:30 & 0.07029 & -0.11919 & 1002.45 & 8/7/99 9:30 & -3.46845 & -4.08092 & 1006.11 \\
\hline 8/5/99 11:30 & 0.54253 & 0.38043 & 1002.36 & 8/7/99 10:30 & -3.46544 & -4.10237 & 1006.25 \\
\hline 8/5/99 12:30 & 0.98468 & 0.85553 & 1001.87 & 8/7/99 11:30 & -3.21128 & -3.83571 & 1006.34 \\
\hline 8/5/99 13:30 & 1.35615 & 1.24787 & 1001.38 & 8/7/99 12:30 & -2.70596 & -3.30850 & 1006.14 \\
\hline 8/5/99 14:30 & 1.63588 & 1.56818 & 1000.96 & 8/7/99 13:30 & -2.23372 & -2.77363 & 1005.71 \\
\hline 8/5/99 15:30 & 2.00585 & 1.93600 & 1000.53 & 8/7/99 14:30 & -1.26219 & -1.71921 & 1005.26 \\
\hline 8/5/99 16:30 & 2.10962 & 2.07547 & 1000.12 & 8/7/99 15:30 & -0.62753 & -1.01882 & 1004.35 \\
\hline 8/5/99 17:30 & 2.07804 & 2.04635 & 999.95 & 8/7/99 16:30 & -0.54030 & -0.92380 & 1003.78 \\
\hline 8/5/99 18:30 & 1.81335 & 1.77355 & 999.95 & 8/7/99 17:30 & -0.33126 & -0.66632 & 1003.75 \\
\hline 8/5/99 19:30 & 1.25539 & 1.23255 & 1000.14 & 8/7/99 18:30 & -0.37637 & -0.74142 & 1003.52 \\
\hline 8/5/99 20:30 & 0.71097 & 0.60725 & 1000.57 & 8/7/99 19:30 & -0.62603 & -0.99736 & 1003.61 \\
\hline 8/5/99 21:30 & -0.08311 & -0.26019 & 1001.16 & 8/7/99 20:30 & -1.09074 & -1.45407 & 1003.90 \\
\hline 8/5/99 22:30 & -0.58241 & -0.78127 & 1001.91 & 8/7/99 21:30 & -1.51334 & -1.90465 & 1004.36 \\
\hline 8/5/99 23:30 & -0.92080 & -1.15215 & 1002.35 & 8/7/99 22:30 & -1.80962 & -2.23416 & 1004.81 \\
\hline 8/6/99 0:30 & -0.97343 & -1.20426 & 1002.58 & 8/7/99 23:30 & -1.85323 & -2.27094 & 1005.09 \\
\hline 8/6/99 1:30 & -0.78995 & -1.01422 & 1002.58 & 8/8/99 0:30 & -1.46973 & -1.83568 & 1005.11 \\
\hline 8/6/99 2:30 & -0.67716 & -0.89774 & 1002.37 & 8/8/99 1:30 & -1.15541 & -1.48626 & 1004.70 \\
\hline 8/6/99 3:30 & -0.77040 & -1.01422 & 1002.31 & 8/8/99 2:30 & -0.60046 & -0.88242 & 1004.41 \\
\hline 8/6/99 4:30 & -0.91779 & -1.17361 & 1002.36 & 8/8/99 3:30 & -0.49970 & -0.77667 & 1003.86 \\
\hline 8/6/99 5:30 & -1.23361 & -1.54296 & 1002.54 & 8/8/99 4:30 & -0.46661 & -0.71843 & 1003.71 \\
\hline
\end{tabular}


Table A-2 Continued

\begin{tabular}{|c|c|c|c|c|c|c|c|}
\hline Date/Time & $\begin{array}{l}\text { MSB 47D } \\
(\mathrm{mb})\end{array}$ & $\begin{array}{l}\text { MSB 68D } \\
(\mathrm{mb})\end{array}$ & $\begin{array}{l}\text { Barometric } \\
\text { Pressure } \\
(\mathrm{mb})\end{array}$ & Date/Time & $\begin{array}{l}\text { MSB 47D } \\
(\mathrm{mb})\end{array}$ & $\begin{array}{l}\text { MSB 68D } \\
(\mathrm{mb})\end{array}$ & $\begin{array}{l}\text { Barometric } \\
\text { Pressure } \\
(\mathrm{mb})\end{array}$ \\
\hline 8/8/99 5:30 & -0.75085 & -1.04181 & 1003.69 & 8/10/99 4:30 & 1.17568 & 1.19117 & 998.68 \\
\hline 8/8/99 6:30 & -1.27723 & -1.64105 & 1004.08 & 8/10/99 5:30 & 0.78616 & 0.80036 & 998.89 \\
\hline 8/8/99 7:30 & -1.78104 & -2.14986 & 1004.73 & 8/10/99 6:30 & 0.37559 & 0.31759 & 999.23 \\
\hline 8/8/99 8:30 & -1.51485 & -1.85254 & 1005.10 & 8/10/99 7:30 & -0.27862 & -0.41038 & 999.69 \\
\hline 8/8/99 9:30 & -1.11931 & -1.46786 & 1004.77 & 8/10/99 8:30 & -0.75837 & -0.94372 & 1000.35 \\
\hline 8/8/99 10:30 & -0.84710 & -1.17974 & 1004.43 & 8/10/99 9:30 & -1.02005 & -1.26710 & 1000.77 \\
\hline 8/8/99 11:30 & -0.49669 & -0.80426 & 1004.14 & 8/10/99 10:30 & -1.18549 & -1.47553 & 1001.08 \\
\hline 8/8/99 12:30 & 0.11692 & -0.12226 & 1003.78 & 8/10/99 11:30 & -0.84109 & -1.10618 & 1001.23 \\
\hline 8/8/99 13:30 & 1.08996 & 0.89231 & 1003.21 & 8/10/99 12:30 & -0.26207 & -0.49927 & 1000.84 \\
\hline 8/8/99 14:30 & 2.33521 & 2.28696 & 1002.18 & 8/10/99 13:30 & 0.18158 & -0.01038 & 1000.31 \\
\hline 8/8/99 15:30 & 3.16688 & 3.21877 & 1000.83 & 8/10/99 14:30 & 0.83128 & 0.71147 & 999.82 \\
\hline 8/8/99 16:30 & 3.00295 & 3.03333 & 999.97 & 8/10/99 15:30 & 1.45090 & 1.35975 & 999.07 \\
\hline 8/8/99 17:30 & 2.72774 & 2.71455 & 1000.10 & 8/10/99 16:30 & 1.58024 & 1.50841 & 998.47 \\
\hline 8/8/99 18:30 & 2.05999 & 2.03102 & 1000.38 & 8/10/99 17:30 & 1.54565 & 1.42872 & 998.34 \\
\hline 8/8/99 19:30 & 1.70958 & 1.69845 & 1001.23 & 8/10/99 18:30 & 1.19222 & 1.05630 & 998.40 \\
\hline 8/8/99 20:30 & 1.38473 & 1.36895 & 1001.33 & 8/10/99 19:30 & 0.65983 & 0.51683 & 998.76 \\
\hline 8/8/99 21:30 & 1.02980 & 0.99193 & 1001.46 & 8/10/99 20:30 & 0.33348 & 0.14748 & 999.10 \\
\hline 8/8/99 22:30 & 1.23283 & 1.23714 & 1001.59 & 8/10/99 21:30 & -0.31471 & -0.54372 & 999.50 \\
\hline 8/8/99 23:30 & 1.53662 & 1.56818 & 1001.32 & 8/10/99 22:30 & -0.68167 & -0.92380 & 1000.10 \\
\hline 8/9/99 0:30 & 1.68852 & 1.73677 & 1000.94 & 8/10/99 23:30 & -0.95839 & -1.20579 & 1000.46 \\
\hline 8/9/99 1:30 & 1.68702 & 1.75516 & 1000.69 & 8/11/99 0:30 & -0.70122 & -0.93606 & 1000.56 \\
\hline 8/9/99 2:30 & 1.97427 & 2.04022 & 1000.49 & 8/11/99 1:30 & -0.54181 & -0.76134 & 1000.38 \\
\hline 8/9/99 3:30 & 1.87802 & 1.97125 & 1000.20 & 8/11/99 2:30 & -0.44555 & -0.65253 & 1000.14 \\
\hline 8/9/99 4:30 & 1.72612 & 1.79194 & 1000.28 & 8/11/99 3:30 & -0.60647 & -0.82571 & 1000.07 \\
\hline 8/9/99 5:30 & 1.26742 & 1.28925 & 1000.49 & $8 / 11 / 994: 30$ & -0.73130 & -0.95598 & 1000.23 \\
\hline 8/9/99 6:30 & 1.24937 & 1.29845 & 1000.79 & 8/11/99 5:30 & -1.05164 & -1.36518 & 1000.37 \\
\hline 8/9/99 7:30 & 1.41932 & 1.48389 & 1000.67 & 8/11/99 6:30 & -1.72690 & -2.08090 & 1000.84 \\
\hline 8/9/99 8:30 & 1.32307 & 1.35209 & 1000.34 & 8/11/99 7:30 & -2.08784 & -2.44719 & 1001.51 \\
\hline 8/9/99 9:30 & 1.16064 & 1.14366 & 1000.52 & 8/11/99 8:30 & -2.14650 & -2.60811 & 1001.86 \\
\hline 8/9/99 10:30 & 1.08845 & 1.04097 & 1000.71 & 8/11/99 9:30 & -2.28185 & -2.73684 & 1001.97 \\
\hline 8/9/99 11:30 & 1.43737 & 1.41646 & 1000.71 & 8/11/99 10:30 & -2.19462 & -2.63723 & 1002.12 \\
\hline 8/9/99 12:30 & 1.90358 & 1.92068 & 1000.30 & 8/11/99 11:30 & -1.78706 & -2.21577 & 1002.11 \\
\hline 8/9/99 13:30 & 2.45402 & 2.53677 & 999.70 & 8/11/99 12:30 & -1.38701 & -1.77898 & 1001.72 \\
\hline 8/9/99 14:30 & 3.26464 & 3.40268 & 999.06 & 8/11/99 13:30 & -0.63204 & -0.94525 & 1001.30 \\
\hline 8/9/99 15:30 & 3.97148 & 4.18583 & 998.01 & 8/11/99 14:30 & 0.26129 & 0.01414 & 1000.54 \\
\hline 8/9/99 16:30 & 4.05420 & 4.25020 & 997.27 & 8/11/99 15:30 & 0.70946 & 0.48465 & 999.64 \\
\hline 8/9/99 17:30 & 4.01811 & 4.23488 & 997.10 & 8/11/99 16:30 & 0.76962 & 0.56127 & 999.28 \\
\hline 8/9/99 18:30 & 3.53234 & 3.68774 & 997.02 & 8/11/99 17:30 & 0.88392 & 0.67009 & 999.11 \\
\hline 8/9/99 19:30 & 2.79240 & 2.87547 & 997.37 & 8/11/99 18:30 & 0.48538 & 0.23790 & 999.04 \\
\hline 8/9/99 20:30 & 2.02239 & 2.08773 & 998.11 & 8/11/99 19:30 & 0.18459 & -0.06862 & 999.43 \\
\hline 8/9/99 21:30 & 1.47797 & 1.49768 & 998.76 & 8/11/99 20:30 & -0.24854 & -0.54065 & 999.63 \\
\hline 8/9/99 22:30 & 1.38774 & 1.42259 & 999.10 & 8/11/99 21:30 & -0.86365 & -1.17361 & 1000.13 \\
\hline 8/9/99 23:30 & 1.39826 & 1.44558 & 999.08 & 8/11/99 22:30 & -1.12232 & -1.51384 & 1000.54 \\
\hline 8/10/99 0:30 & 1.52459 & 1.59270 & 998.98 & 8/11/99 23:30 & -1.62614 & -2.00427 & 1001.04 \\
\hline 8/10/99 1:30 & 1.49903 & 1.56358 & 998.74 & 8/12/99 0:30 & -1.51785 & -1.90312 & 1001.38 \\
\hline 8/10/99 2:30 & 1.48399 & 1.53753 & 998.74 & 8/12/99 1:30 & -1.23060 & -1.58128 & 1001.33 \\
\hline 8/10/99 3:30 & 1.40428 & 1.44404 & 998.66 & 8/12/99 2:30 & -1.21707 & -1.50465 & 1000.99 \\
\hline
\end{tabular}


Table A-2 Continued

\begin{tabular}{|c|c|c|c|c|c|c|c|}
\hline Date/Time & $\begin{array}{l}\text { MSB 47D } \\
(\mathrm{mb})\end{array}$ & $\begin{array}{l}\text { MSB 68D } \\
(\mathrm{mb})\end{array}$ & $\begin{array}{l}\text { Barometric } \\
\text { Pressure } \\
(\mathrm{mb})\end{array}$ & Date/Time & $\begin{array}{l}\text { MSB 47D } \\
(\mathrm{mb})\end{array}$ & $\begin{array}{l}\text { MSB 68D } \\
(\mathrm{mb})\end{array}$ & $\begin{array}{l}\text { Barometric } \\
\text { Pressure } \\
(\mathrm{mb})\end{array}$ \\
\hline 8/12/99 3:30 & -1.08623 & -1.41116 & 1000.91 & 8/12/99 6:30 & -1.64870 & -1.99661 & 1001.30 \\
\hline 8/12/99 4:30 & -1.18097 & -1.52304 & 1000.87 & 8/12/99 7:02 & -1.75397 & -2.12841 & 1001.54 \\
\hline 8/12/99 5:30 & -1.50733 & -1.88319 & 1001.01 & & & & \\
\hline
\end{tabular}


Table A-3. Vadose Zone Differential Pressures and Barometric Pressure Recorded During SVE Testing on MSB 68D.

\begin{tabular}{|c|c|c|c|c|c|c|c|}
\hline Date/Time & $\begin{array}{l}\text { MSB 47D } \\
(\mathrm{mb})\end{array}$ & $\begin{array}{l}\text { MSB 67D } \\
(\mathrm{mb})\end{array}$ & $\begin{array}{l}\text { Barometric } \\
\text { Pressure } \\
(\mathrm{mb})\end{array}$ & Date/Time & $\begin{array}{l}\text { MSB 47D } \\
(\mathrm{mb})\end{array}$ & $\begin{array}{l}\text { MSB 67D } \\
(\mathrm{mb})\end{array}$ & $\begin{array}{l}\text { Barometric } \\
\text { Pressure } \\
(\mathrm{mb})\end{array}$ \\
\hline 7/26/99 7:40 & -0.93168 & -0.83615 & 1003.33 & 7/28/99 13:30 & -1.05100 & -1.03961 & 1004.96 \\
\hline 7/26/99 8:30 & -1.13836 & -1.01103 & 1003.58 & 7/28/99 14:30 & -0.29237 & -0.35682 & 1004.23 \\
\hline 7/26/99 9:30 & -1.25024 & -1.08322 & 1003.83 & |7/28/99 15:30 & 0.48158 & 0.34852 & 1003.62 \\
\hline 7/26/99 10:30 & -1.35905 & -1.17797 & 1004.02 & 7/28/99 16:30 & 1.20189 & 0.99070 & 1002.93 \\
\hline 7/26/99 11:30 & -1.11690 & -0.94335 & 1004.05 & 7/28/99 17:30 & 1.48695 & 1.28246 & 1002.26 \\
\hline 7/26/99 12:30 & -0.82878 & -0.66964 & 1003.84 & |7/28/99 18:30 & 1.37048 & 1.20426 & 1001.98 \\
\hline 7/26/99 13:30 & -0.18663 & -0.08762 & 1003.52 & |7/28/99 19:30 & 0.91224 & 0.78165 & 1002.14 \\
\hline 7/26/99 14:30 & 0.38656 & 0.41319 & 1002.91 & 7/28/99 20:30 & 0.69461 & 0.56208 & 1002.44 \\
\hline 7/26/99 15:30 & 0.91530 & 0.88392 & 1002.45 & |7/28/99 21:30 & 0.52909 & 0.39815 & 1002.62 \\
\hline 7/26/99 16:30 & 1.33676 & 1.28096 & 1001.88 & |7/28/99 22:30 & 0.54135 & 0.38913 & 1002.77 \\
\hline 7/26/99 17:30 & 1.66473 & 1.58325 & 1001.42 & 7/28/99 23:30 & 0.65476 & 0.49891 & 1002.71 \\
\hline 7/26/99 18:30 & 1.66933 & 1.64040 & 1000.97 & 7/29/99 0:30 & 0.54288 & 0.38311 & 1002.59 \\
\hline 7/26/99 19:30 & 1.02718 & 1.01326 & 1001.05 & 7/29/99 1:30 & 1.12527 & 0.90347 & 1002.55 \\
\hline 7/26/99 20:30 & 0.42947 & 0.43876 & 1001.61 & 7/29/99 2:30 & 1.63715 & 1.36367 & 1001.96 \\
\hline 7/26/99 21:30 & -0.16210 & -0.11469 & 1002.15 & 7/29/99 3:30 & 1.64941 & 1.38322 & 1001.48 \\
\hline 7/26/99 22:30 & -0.51153 & -0.41848 & 1002.63 & 7/29/99 4:30 & 1.64634 & 1.38172 & 1001.41 \\
\hline 7/26/99 23:30 & -0.50234 & -0.42901 & 1002.83 & 7/29/99 5:30 & 1.08389 & 0.88693 & 1001.41 \\
\hline 7/27/99 0:30 & -0.33069 & -0.28163 & 1002.82 & 7/29/99 6:30 & 0.92143 & 0.73353 & 1001.93 \\
\hline 7/27/99 1:30 & 0.01568 & 0.02518 & 1002.60 & 7/29/99 7:30 & 0.86626 & 0.67938 & 1002.04 \\
\hline 7/27/99 2:30 & 0.02181 & 0.02518 & 1002.31 & 7/29/99 8:30 & 0.63944 & 0.64179 & 1002.11 \\
\hline 7/27/99 3:30 & -0.17590 & -0.14026 & 1002.31 & 7/29/99 9:30 & 0.46932 & 0.82978 & 1002.10 \\
\hline 7/27/99 4:30 & -0.44257 & -0.40344 & 1002.44 & |7/29/99 10:30 & 1.18810 & 1.11252 & 1001.93 \\
\hline 7/27/99 5:30 & -0.90541 & -0.82154 & 1002.73 & |7/29/99 11:30 & 1.69692 & 1.58174 & 1001.60 \\
\hline 7/27/99 6:30 & -1.57821 & -1.42160 & 1003.12 & 7/29/99 12:30 & 2.12451 & 1.97276 & 1001.11 \\
\hline 7/27/99 7:30 & -2.26481 & -2.03821 & 1003.84 & |7/29/99 13:30 & 2.63486 & 2.44500 & 1000.67 \\
\hline 7/27/99 8:30 & -2.59278 & -2.33900 & 1004.47 & |7/29/99 14:30 & 3.14674 & 2.96686 & 1000.13 \\
\hline 7/27/99 9:30 & -2.51768 & -2.26380 & 1004.79 & 7/29/99 15:30 & 3.56667 & 3.40150 & 999.47 \\
\hline 7/27/99 10:30 & -2.56060 & -2.27132 & 1004.78 & |7/29/99 16:30 & 3.98047 & 3.84064 & 998.76 \\
\hline 7/27/99 11:30 & -2.15140 & -1.88632 & 1004.86 & |7/29/99 17:30 & 3.98353 & 3.83764 & 998.12 \\
\hline 7/27/99 12:30 & -1.93837 & -1.71036 & 1004.51 & 7/29/99 18:30 & 3.16054 & 3.00897 & 998.09 \\
\hline 7/27/99 13:30 & -1.25943 & -1.11029 & 1004.37 & |7/29/99 19:30 & 2.55210 & 2.43447 & 998.50 \\
\hline 7/27/99 14:30 & -0.89468 & -0.77642 & 1003.75 & |7/29/99 20:30 & 2.48160 & 2.36078 & 998.73 \\
\hline 7/27/99 15:30 & -0.32303 & -0.22748 & 1003.40 & |7/29/99 21:30 & 2.13524 & 2.03593 & 999.05 \\
\hline 7/27/99 16:30 & -0.09314 & -0.02295 & 1002.92 & |7/29/99 22:30 & 2.24558 & 2.12616 & 999.11 \\
\hline 7/27/99 17:30 & -0.11459 & -0.04701 & 1002.71 & |7/29/99 23:30 & 1.89156 & 1.84343 & 998.92 \\
\hline 7/27/99 18:30 & -0.14678 & -0.05453 & 1002.75 & 7/30/99 0:30 & 1.95286 & 1.87952 & 999.08 \\
\hline 7/27/99 19:30 & -0.51000 & -0.41698 & 1002.73 & 7/30/99 1:30 & 2.08619 & 2.00134 & 998.87 \\
\hline 7/27/99 20:30 & -1.07246 & -0.93583 & 1003.06 & 7/30/99 2:30 & 1.98351 & 1.90358 & 998.66 \\
\hline 7/27/99 21:30 & -1.57668 & -1.40356 & 1003.51 & 7/30/99 3:30 & 2.04022 & 1.96524 & 998.63 \\
\hline 7/27/99 22:30 & -1.79277 & -1.61711 & 1004.02 & 7/30/99 4:30 & 1.89309 & 1.82839 & 998.50 \\
\hline 7/27/99 23:30 & -1.62879 & -1.48026 & 1004.11 & |7/30/99 5:30 & 1.19883 & 1.22531 & 998.57 \\
\hline 7/28/99 0:30 & -1.32687 & -1.21406 & 1004.00 & |7/30/99 6:30 & 0.42487 & 0.51094 & 999.13 \\
\hline 7/28/99 1:30 & -1.11077 & -1.02156 & 1003.79 & 7/30/99 7:30 & 0.11989 & 0.24174 & 999.79 \\
\hline 7/28/99 2:30 & -0.89621 & -0.82906 & 1003.53 & 7/30/99 8:30 & -0.39506 & -0.19891 & 999.98 \\
\hline 7/28/99 3:30 & -1.04947 & -0.98246 & 1003.45 & 7/30/99 9:30 & -0.90234 & -0.63505 & 1000.43 \\
\hline 7/28/99 4:30 & -1.06173 & -0.98546 & 1003.53 & 7/30/99 10:30 & -0.82725 & -0.53729 & 1000.86 \\
\hline 7/28/99 5:30 & -1.42189 & -1.31332 & 1003.59 & |7/30/99 11:30 & -0.57130 & -0.29366 & 1000.74 \\
\hline 7/28/99 6:30 & -1.90465 & -1.75247 & 1003.94 & 7/30/99 12:30 & -0.38586 & -0.11319 & 1000.53 \\
\hline 7/28/99 7:30 & -2.33377 & -2.13146 & 1004.44 & 7/30/99 13:30 & 0.35284 & 0.55155 & 1000.30 \\
\hline 7/28/99 8:30 & -2.61117 & -2.38412 & 1004.88 & 7/30/99 14:30 & 0.83407 & 0.99070 & 999.50 \\
\hline 7/28/99 9:30 & -2.69393 & -2.48638 & 1005.19 & |7/30/99 15:30 & 1.27546 & 1.37270 & 998.96 \\
\hline 7/28/99 10:30 & -2.84412 & -2.64580 & 1005.48 & 7/30/99 16:30 & 1.62795 & 1.69754 & 998.54 \\
\hline 7/28/99 11:30 & -2.44872 & -2.30291 & 1005.75 & 7/30/99 17:30 & 1.89002 & 1.97276 & 998.15 \\
\hline 7/28/99 12:30 & -1.85101 & -1.74645 & 1005.44 & 7/30/99 18:30 & 2.07240 & 2.12767 & 997.85 \\
\hline
\end{tabular}


Table A-3 Continued

\begin{tabular}{|c|c|c|c|c|c|c|c|}
\hline Date/Time & $\begin{array}{l}\text { MSB 47D } \\
(\mathrm{mb})\end{array}$ & $\begin{array}{l}\text { MSB 67D } \\
(\mathrm{mb})\end{array}$ & $\begin{array}{l}\text { Barometric } \\
\text { Pressure } \\
(\mathrm{mb})\end{array}$ & Date/Time & $\begin{array}{l}\text { MSB 47D } \\
(\mathrm{mb})\end{array}$ & $\begin{array}{l}\text { MSB 67D } \\
(\mathrm{mb})\end{array}$ & $\begin{array}{l}\text { Barometric } \\
\text { Pressure } \\
(\mathrm{mb})\end{array}$ \\
\hline 7/30/99 19:30 & 1.59424 & 1.64491 & 997.65 & $8 / 2 / 99$ 1:30 & -2.22343 & -1.86225 & 1001.74 \\
\hline 7/30/99 20:30 & 0.65476 & 0.80872 & 998.05 & 8/2/99 2:30 & -2.12841 & -1.77954 & 1001.42 \\
\hline 7/30/99 21:30 & -0.09314 & 0.09135 & 998.84 & 8/2/99 3:30 & -2.17898 & -1.84421 & 1001.40 \\
\hline 7/30/99 22:30 & -0.02724 & 0.16203 & 999.42 & 8/2/99 4:30 & -2.37975 & -2.02468 & 1001.46 \\
\hline 7/30/99 23:30 & -0.02264 & 0.14850 & 999.29 & 8/2/99 5:30 & -2.91156 & -2.48939 & 1001.75 \\
\hline 7/31/99 0:30 & 0.13675 & 0.28536 & 999.26 & 8/2/99 6:30 & -3.33915 & -2.88041 & 1002.29 \\
\hline 7/31/99 1:30 & 0.27008 & 0.39965 & 998.95 & 8/2/99 7:30 & -3.86176 & -3.34964 & 1002.73 \\
\hline 7/31/99 2:30 & 0.46166 & 0.56659 & 998.79 & 8/2/99 8:30 & -4.26483 & -3.70457 & 1003.39 \\
\hline 7/31/99 3:30 & 0.45093 & 0.55606 & 998.51 & 8/2/99 9:30 & -4.37824 & -3.81135 & 1003.68 \\
\hline 7/31/99 4:30 & 0.05246 & 0.19362 & 998.52 & 8/2/99 10:30 & -4.63725 & -4.01889 & 1003.87 \\
\hline 7/31/99 5:30 & -0.14218 & 0.01465 & 998.84 & 8/2/99 11:30 & -4.36445 & -3.78728 & 1004.20 \\
\hline 7/31/99 6:30 & -1.30388 & -1.03359 & 999.13 & 8/2/99 12:30 & -3.82191 & -3.30001 & 1003.90 \\
\hline 7/31/99 7:30 & -1.64105 & -1.32686 & 1000.13 & 8/2/99 13:30 & -3.43877 & -2.95411 & 1003.52 \\
\hline 7/31/99 8:30 & -2.13147 & -1.75247 & 1000.30 & 8/2/99 14:30 & -2.92382 & -2.47887 & 1003.25 \\
\hline 7/31/99 9:30 & -2.52535 & -2.09386 & 1000.90 & 8/2/99 15:30 & -2.43033 & -2.05777 & 1002.78 \\
\hline 7/31/99 10:30 & -2.99585 & -2.51797 & 1001.34 & 8/2/99 16:30 & -1.99507 & -1.64268 & 1002.37 \\
\hline 7/31/99 11:30 & -2.65715 & -2.19613 & 1001.71 & 8/2/99 17:30 & -1.70235 & -1.39152 & 1002.03 \\
\hline 7/31/99 12:30 & -2.29086 & -1.84270 & 1001.32 & 8/2/99 18:30 & -1.86174 & -1.51034 & 1001.82 \\
\hline 7/31/99 13:30 & -1.82189 & -1.44115 & 1001.08 & 8/2/99 19:30 & -2.42573 & -2.03821 & 1002.00 \\
\hline 7/31/99 14:30 & -1.20120 & -0.85161 & 1000.59 & 8/2/99 20:30 & -3.01118 & -2.56760 & 1002.66 \\
\hline 7/31/99 15:30 & -0.83797 & -0.52526 & 1000.08 & 8/2/99 21:30 & -3.39892 & -2.94659 & 1003.15 \\
\hline 7/31/99 16:30 & -0.60655 & -0.29215 & 999.68 & 8/2/99 22:30 & -3.56291 & -3.09848 & 1003.54 \\
\hline 7/31/99 17:30 & -0.47169 & -0.18989 & 999.46 & 8/2/99 23:30 & -3.65946 & -3.17970 & 1003.79 \\
\hline 7/31/99 18:30 & -0.32456 & -0.07559 & 999.37 & 8/3/99 0:30 & -3.44949 & -3.01126 & 1003.87 \\
\hline 7/31/99 19:30 & -0.89468 & -0.59595 & 999.27 & 8/3/99 1:30 & -2.98512 & -2.57812 & 1003.63 \\
\hline 7/31/99 20:30 & -1.88319 & -1.51334 & 999.85 & 8/3/99 2:30 & -2.74144 & -2.37209 & 1003.21 \\
\hline 7/31/99 21:30 & -2.49929 & -2.06980 & 1000.70 & 8/3/99 3:30 & -3.38972 & -2.96313 & 1003.17 \\
\hline 7/31/99 22:30 & -2.66481 & -2.23072 & 1001.18 & 8/3/99 4:30 & -3.94605 & -3.46394 & 1003.90 \\
\hline 7/31/99 23:30 & -2.59431 & -2.17507 & 1001.40 & 8/3/99 5:30 & -4.28782 & -3.77976 & 1004.37 \\
\hline 8/1/99 0:30 & -2.20964 & -1.83970 & 1001.30 & 8/3/99 6:30 & -4.70315 & -4.17981 & 1004.82 \\
\hline 8/1/99 1:30 & -1.74679 & -1.41108 & 1000.92 & 8/3/99 7:30 & -4.88093 & -4.43848 & 1005.30 \\
\hline 8/1/99 2:30 & -1.21959 & -0.96892 & 1000.46 & 8/3/99 8:30 & -5.18744 & -4.71220 & 1005.92 \\
\hline 8/1/99 3:30 & -1.17054 & -0.91929 & 999.93 & 8/3/99 9:30 & -5.07250 & -4.62347 & 1006.35 \\
\hline 8/1/99 4:30 & -1.32993 & -1.06818 & 999.97 & 8/3/99 10:30 & -4.75679 & -4.30614 & 1006.43 \\
\hline 8/1/99 5:30 & -1.80810 & -1.49981 & 1000.18 & 8/3/99 11:30 & -4.17747 & -3.78728 & 1006.29 \\
\hline 8/1/99 6:30 & -2.36749 & -2.01415 & 1000.66 & 8/3/99 12:30 & -3.52459 & -3.20977 & 1005.93 \\
\hline 8/1/99 7:30 & -2.92842 & -2.50443 & 1001.19 & 8/3/99 13:30 & -2.57286 & -2.34201 & 1005.36 \\
\hline 8/1/99 8:30 & -3.34068 & -2.87289 & 1001.75 & 8/3/99 14:30 & -1.87400 & -1.72389 & 1004.59 \\
\hline 8/1/99 9:30 & -3.58130 & -3.08194 & 1002.11 & 8/3/99 15:30 & -1.46020 & -1.32535 & 1004.00 \\
\hline 8/1/99 10:30 & -3.71463 & -3.16014 & 1002.44 & 8/3/99 16:30 & -1.15982 & -1.10578 & 1003.57 \\
\hline 8/1/99 11:30 & -3.65333 & -3.10300 & 1002.66 & 8/3/99 17:30 & -1.03108 & -0.94185 & 1003.33 \\
\hline 8/1/99 12:30 & -3.21348 & -2.67438 & 1002.63 & 8/3/99 18:30 & -1.00349 & -0.91478 & 1003.32 \\
\hline 8/1/99 13:30 & -2.85025 & -2.39916 & 1002.24 & 8/3/99 19:30 & -1.27169 & -1.18699 & 1003.39 \\
\hline 8/1/99 14:30 & -2.30312 & -1.90888 & 1001.99 & 8/3/99 20:30 & -1.70388 & -1.59456 & 1003.72 \\
\hline 8/1/99 15:30 & -1.71308 & -1.35092 & 1001.47 & 8/3/99 21:30 & -1.96902 & -1.82466 & 1004.17 \\
\hline 8/1/99 16:30 & -1.02342 & -0.72829 & 1001.00 & 8/3/99 22:30 & -1.66863 & -1.58102 & 1004.35 \\
\hline 8/1/99 17:30 & -0.59429 & -0.31170 & 1000.38 & 8/3/99 23:30 & -1.51997 & -1.44717 & 1004.11 \\
\hline 8/1/99 18:30 & -0.99276 & -0.66964 & 999.96 & 8/4/99 0:30 & -1.06480 & -1.05765 & 1003.95 \\
\hline 8/1/99 19:30 & -1.80810 & -1.41258 & 1000.38 & 8/4/99 1:30 & -0.78127 & -0.77491 & 1003.57 \\
\hline 8/1/99 20:30 & -2.17898 & -1.80661 & 1001.09 & 8/4/99 2:30 & -0.47015 & -0.57489 & 1003.30 \\
\hline 8/1/99 21:30 & -2.63723 & -2.21718 & 1001.45 & 8/4/99 3:30 & -0.34908 & -0.43954 & 1003.07 \\
\hline 8/1/99 22:30 & -2.73991 & -2.32998 & 1001.96 & 8/4/99 4:30 & -0.35674 & -0.42450 & 1002.98 \\
\hline 8/1/99 23:30 & -2.69087 & -2.29087 & 1001.93 & 8/4/99 5:30 & -0.86403 & -0.88320 & 1003.07 \\
\hline 8/2/99 0:30 & -2.56673 & -2.17357 & 1002.01 & 8/4/99 6:15 & -1.48604 & -1.42654 & 1003.44 \\
\hline
\end{tabular}


Table A-4. Vadose Zone Differential Pressures and Barometric Pressure Recorded During SVE Testing on MSB 68D.

\begin{tabular}{|c|c|c|c|c|c|c|c|}
\hline Date/Time & $\begin{array}{l}\text { MSB 47D } \\
(\mathrm{mb})\end{array}$ & $\begin{array}{l}\text { MSB 67D } \\
(\mathrm{mb})\end{array}$ & $\begin{array}{l}\text { Barometric } \\
\text { Pressure } \\
(\mathrm{mb})\end{array}$ & Date/Time & $\begin{array}{l}\text { MSB 47D } \\
(\mathrm{mb})\end{array}$ & $\begin{array}{l}\text { MSB 67D } \\
(\mathrm{mb})\end{array}$ & $\begin{array}{l}\text { Barometric } \\
\text { Pressure } \\
(\mathrm{mb})\end{array}$ \\
\hline 8/16/99 7:30 & - & -6.54850 & 1009.50 & $8 / 18 / 99$ 13:30 & 3.64943 & 3.64964 & 1001.45 \\
\hline 8/16/99 8:30 & - & -6.96809 & 1010.18 & 8/18/99 14:30 & 4.56438 & 4.46929 & 1000.67 \\
\hline 8/16/99 9:30 & - & -7.19218 & 1010.86 & 8/18/99 15:30 & 5.09772 & 4.98664 & 999.69 \\
\hline 8/16/99 10:30 & - & -7.12751 & 1011.39 & 8/18/99 16:30 & 5.04255 & 4.94603 & 999.08 \\
\hline 8/16/99 11:30 & - & -5.99655 & 1011.51 & 8/18/99 17:30 & 4.71917 & 4.65878 & 999.05 \\
\hline 8/16/99 12:30 & - & -3.25188 & 1011.06 & 8/18/99 18:30 & 4.34369 & 4.34145 & 999.23 \\
\hline 8/16/99 13:30 & - & -5.39198 & 1010.37 & 8/18/99 19:30 & 3.75978 & 3.78801 & 999.38 \\
\hline 8/16/99 14:30 & - & -4.72573 & 1010.02 & 8/18/99 20:30 & 2.79118 & 2.89166 & 999.84 \\
\hline 8/16/99 15:30 & - & -4.87613 & 1010.10 & 8/18/99 21:30 & 1.85171 & 2.00886 & 1000.62 \\
\hline 8/16/99 16:30 & - & -4.29411 & 1010.13 & 8/18/99 22:30 & 1.72757 & 1.90659 & 1001.29 \\
\hline 8/16/99 17:30 & - & -3.99332 & 1009.40 & 8/18/99 23:30 & 1.77202 & 1.95472 & 1001.29 \\
\hline 8/16/99 18:30 & - & -3.58425 & 1009.27 & 8/19/99 0:30 & 1.84405 & 2.01187 & 1001.11 \\
\hline 8/16/99 19:30 & - & -3.67148 & 1008.85 & 8/19/99 1:30 & 1.81799 & 1.97577 & 1000.90 \\
\hline 8/16/99 20:30 & - & -4.24899 & 1009.35 & 8/19/99 2:30 & 1.71991 & 1.89606 & 1000.80 \\
\hline 8/16/99 21:30 & - & -4.53323 & 1010.01 & 8/19/99 3:30 & 1.61876 & 1.79530 & 1000.62 \\
\hline 8/16/99 22:30 & - & -4.36329 & 1010.31 & 8/19/99 4:30 & 1.26780 & 1.46744 & 1000.83 \\
\hline 8/16/99 23:30 & - & -4.23395 & 1010.32 & 8/19/99 5:30 & 0.86166 & 1.08845 & 1000.98 \\
\hline 8/17/99 0:30 & - & -3.93768 & 1010.28 & 8/19/99 6:20 & 0.23075 & 0.52999 & 1001.38 \\
\hline 8/17/99 1:30 & - & -3.39325 & 1010.07 & & & & \\
\hline 8/17/99 2:30 & - & -3.26993 & 1009.65 & & & & \\
\hline 8/17/99 3:30 & - & -3.06540 & 1009.61 & & & & \\
\hline 8/17/99 4:30 & - & -2.88944 & 1009.50 & & & & \\
\hline 8/17/99 5:30 & - & -2.86838 & 1009.42 & & & & \\
\hline 8/17/99 6:30 & - & -2.98569 & 1009.54 & & & & \\
\hline 8/17/99 7:30 & - & -2.88342 & 1009.67 & & & & \\
\hline 8/17/99 8:30 & - & -2.99471 & 1009.70 & & & & \\
\hline 8/17/99 9:30 & - & -2.85184 & 1009.93 & & & & \\
\hline 8/17/99 10:30 & -2.53608 & -2.31945 & 1009.80 & & & & \\
\hline 8/17/99 11:30 & -1.81576 & -1.58854 & 1009.43 & & & & \\
\hline 8/17/99 12:30 & -1.10311 & -0.83056 & 1008.79 & & & & \\
\hline 8/17/99 13:30 & -0.24946 & -0.01242 & 1007.90 & & & & \\
\hline 8/17/99 14:30 & 0.83867 & 0.99220 & 1006.80 & & & & \\
\hline 8/17/99 15:30 & 1.60037 & 1.70206 & 1005.71 & & & & \\
\hline 8/17/99 16:30 & 2.00957 & 2.09759 & 1004.90 & & & & \\
\hline 8/17/99 17:30 & 2.29003 & 2.35326 & 1004.42 & & & & \\
\hline 8/17/99 18:30 & 1.90382 & 1.99833 & 1004.24 & & & & \\
\hline 8/17/99 19:30 & 1.49922 & 1.61784 & 1004.41 & & & & \\
\hline 8/17/99 20:30 & 1.32757 & 1.46143 & 1004.71 & & & & \\
\hline 8/17/99 21:30 & 0.67622 & 0.86136 & 1004.74 & & & & \\
\hline 8/17/99 22:30 & 0.77277 & 0.93806 & 1005.16 & & & & \\
\hline 8/17/99 23:30 & 0.99193 & 1.13056 & 1005.14 & & & & \\
\hline 8/18/99 0:30 & 1.28006 & 1.39225 & 1004.79 & & & & \\
\hline 8/18/99 1:30 & 1.64941 & 1.73815 & 1004.40 & & & & \\
\hline 8/18/99 2:30 & 1.83179 & 1.90358 & 1003.94 & & & & \\
\hline 8/18/99 3:30 & 1.97432 & 2.02540 & 1003.67 & & & & \\
\hline 8/18/99 4:30 & 2.07853 & 2.11113 & 1003.41 & & & & \\
\hline 8/18/99 5:30 & 1.76742 & 1.83741 & 1003.24 & & & & \\
\hline 8/18/99 6:30 & 1.36282 & 1.46895 & 1003.46 & & & & \\
\hline 8/18/99 7:30 & 1.39347 & 1.47948 & 1003.77 & & & & \\
\hline 8/18/99 8:30 & 1.48389 & 1.57573 & 1003.59 & & & & \\
\hline 8/18/99 9:30 & 1.60496 & 1.70356 & 1003.40 & & & & \\
\hline 8/18/99 10:30 & 1.73370 & 1.83591 & 1003.19 & & & & \\
\hline 8/18/99 11:30 & 2.41110 & 2.47658 & 1002.97 & & & & \\
\hline $8 / 18 / 9912: 30$ & 3.04559 & 3.04356 & 1002.24 & & & & \\
\hline
\end{tabular}

